\title{
A Review on Coastal Urban Ecology: Research Gaps, Challenges, and Needs
}

\author{
Giorgia Graells ${ }^{1,2,3 *}$, Nao Nakamura ${ }^{4}$, Juan L. Celis-Diez ${ }^{5}$, Nelson A. Lagos ${ }^{3,6}$, \\ Pablo A. Marquet ${ }^{1,7}$, Patricio Pliscoff ${ }^{1}$ and Stefan Gelcich ${ }^{1,2,3}$
}

1 Departamento de Ecología, Facultad de Ciencias Biológicas, Pontificia Universidad Católica de Chile, Santiago, Chile, ${ }^{2}$ Center of Applied Ecology and Sustainability (CAPES), Santiago, Chile, ${ }^{3}$ Instituto Milenio en Socio-Ecología Costera (SECOS), Santiago, Chile, ${ }^{4}$ Australian Research Council Centre of Excellence for Coral Reef Studies, James Cook University, Townsville, QLD, Australia, ${ }^{5}$ Pontificia Universidad Católica de Valparaíso, Escuela de Agronomía, Quillota, Chile, ${ }^{6}$ Centro de Investigación e Innovación para el Cambio Climático, Facultad de Ciencias, Universidad Santo Tomás, Santiago, Chile,

${ }^{7}$ Instituto de Ecología y Biodiversidad (IEB), Santiago, Chile

\section{OPEN ACCESS}

Edited by:

Iris Eline Hendriks,

Consejo Superior de Investigaciones

Cientificas (CSIC), Spain

Reviewed by:

Robert Francis,

King's College London,

United Kingdom

Joshua Cousins,

SUNY College of Environmental Science and Forestry, United States

${ }^{*}$ Correspondence: Giorgia Graells gygrael/@uc.c

Specialty section: This article was submitted to Global Change and the Future Ocean, a section of the journal Frontiers in Marine Science

Received: 15 October 2020 Accepted: 23 April 2021 Published: 26 May 2021

Citation: Graells G, Nakamura N, Celis-Diez JL, Lagos NA, Marquet PA, Pliscoff $P$ and Gelcich S (2021) A Review on Coastal

Urban Ecology: Research Gaps,

Challenges, and Needs.

Front. Mar. Sci. 8:617897.

doi: 10.3389/fmars.2021.617897
Coastal urban areas have dramatically increased during the last decades, however, coastal research integrating the impacts and challenges facing urban areas is still scarce. To examine research advances and critical gaps, a review of the literature on coastal urban ecology was performed. Articles were selected following a structured decision tree and data were classified into study disciplines, approaches, type of analysis, main research objectives, and Pickett's paradigms in-, of-, and for- the city, among other categories. From a total of 237 publications, results show that most of the research comes from the USA, China, and Australia, and has been carried out mostly in large cities with populations between 1 and 5 million people. Focus has been placed on ecological studies, spatial and quantitative analysis and pollution in coastal urban areas. Most of the studies on urban ecology in coastal zones were developed at nearshore terrestrial environments and only $22.36 \%$ included the marine ecosystem. Urban ecological studies in coastal areas have mainly been carried out under the paradigm in the city with a focus on the disciplines of biology and ecology. Results suggest a series of disciplinary, geographical, and approach biases which can present a number of risks. Foremost among these is a lack of knowledge on social dimensions which can impact on sustainability. A key risk relates to the fact that lessons and recommendations of research are mainly from developed countries and large cities which might have different institutional, planning and cultural settings compared to developing and mid-income countries. Scientific research on coastal urban areas needs to diversify toward an ecology of and for the cities, in order to support coastal development in a diversity of countries and settings.

Keywords: coastal urban ecology, marine urbanization, coastal cities, urban ecology paradigms, coastal urbanization

\section{INTRODUCTION}

The world's population is increasing annually. In 2018, 55\% of the human population lived in urban areas and cities have been constantly growing in number and size, forming large cities. The socalled megacities have reached over 10 million inhabitants (according to the United Nations, 2018, presenting 33 settlements). The high levels of urbanization during the last decades have triggered 
increasing research and policy interest on the impacts and sustainability of these human-dominated ecosystems (Grimm et al., 2000; Griggs et al., 2013). Initial research hypothesized urban areas were not able to sustain wildlife and complex ecological processes. However, this began changing in the first part of the "70s when urban ecology began studying species distributions in cities and its drivers (Noyes and Progulske, 1974; Dorney et al., 1984; Sukopp, 1998; Grimm et al., 2008). Since then, urban ecology research topics have evolved to include ecological and social science approaches (Grimm et al., 2000) and currently, urban ecosystems are recognized as a complex coupling of ecological processes and human dynamics, as defined by Alberti (2008) and Pickett et al. (2008). Research on urban ecology is diverse and includes studies on biodiversity patterns [e.g., urban biodiversity in Faeth et al. (2011); biotic homogenization in McKinney, 2006], species distributions (e.g., birds in Marzluff, 2001), ecosystem functions (Groffman et al., 2004; Rosenzweig et al., 2018), development processes (e.g., Antrop, 2004), drivers of change (e.g., Grimm et al., 2008), ecosystem services (Bolund and Hunhammar, 1999; Daily, 2003), human well-being (Pacione, 2003; Van Kamp et al., 2003; Dallimer et al., 2012), social-ecological systems (Barthel et al., 2010; Grimm et al., 2013), and sustainability (Wu, 2008, 2014).

Pickett et al. (2016) introduced three phases in the way urban ecology has evolved. They provide a typology of paradigms for urban ecology, which are termed: in, of, and for the city. Each one of these paradigms exposes historical differences according to changes in urban ecology research, and resulted by the comparison of three variables: chronology, model approach, and complexity. Studies under the paradigm in the city fall mainly into using ecological approaches, studies of the city are mainly based on social-ecological interactions, and studies for the city represent research about environmental policies and planning. The urban ecology paradigms also represent increasing level of complexity of the system studied, where research which subscribe to the of the city paradigm include interdisciplinary research; the urban ecology for the city is more intricate and includes in and of the city studies, engaging scientific knowledge in practice for action (Pickett et al., 2016).

Most of the theoretical and empirical developments in urban ecology have used green areas (e.g., Chiesura, 2004; Tzoulas et al., 2007; Wolch et al., 2014), freshwater streams (e.g., Allan et al., 1997; Paul and Meyer, 2001; Walsh et al., 2005), and organisms such as birds (e.g., Blair, 1996; Chace and Walsh, 2006) or plants (e.g., Ulrich, 1984; Donovan and Prestemon, 2012; Donovan et al., 2013) as their preferred research subjects. Coastal settings and species have not received the attention they deserve, and only $5 \%$ of urban ecology research in Web of Science is focused in coastal or marine ecosystems. This is unfortunate because coastal cities present a variety of environments, including the land-marine ecotone interaction, and they are an important place for people to settle (Weinstein, 2009). According to the (United Nations, 2017), $40 \%$ of the world's population live $<100 \mathrm{Km}$ from the sea, and these cities have increased their population 6.6 times between 1945 and 2012 (Barragán and de Andrés, 2015). These factors and specific features such as interactions with watersheds in estuaries, the establishment of structures in ports (Cadenasso et al., 2006), and the social importance of access to the waterfront (Sairinen and Kumpulainen, 2006) reflect a particular vulnerability for coastal urban areas. During recent decades, studies on risks have increased due to predicted changes in winds, waves or sea-level rise due to climate change (Torresan et al., 2008; Kumar et al., 2010; Benveniste et al., 2019). Despite recent interest on vulnerabilities, research has mainly focused on geomorphological contexts (Arns et al., 2017; Vitousek et al., 2017; Luijendijk et al., 2018; Benveniste et al., 2019).

This article reviews scientific publications of coastal urban ecology with the aim of examining spatial and temporal changes in time and evaluating the evolution of urban ecology in these vulnerable areas through identifying the interconnection in existing literature given by the urban ecology paradigms (Pickett et al., 2016). Here, studies are classified according to theoretical and empirical dimensions of urban ecology. Biases in the literature are highlighted as a way to call attention to the needs for developing coastal urban ecology studies that can inform ongoing urbanization trends, especially in developing and mid-income countries.

\section{METHODS}

A review of the literature was performed through the Web of Science database (https://webofknowledge.com/). Eligibility criteria included any publication following keywords in the topic, using Boolean operators to combine concepts and keywords: ("urban ecology" or "urban environment*") and (coast* or marine). The period of the search included from 1975 until December 2019. We based our search on systematic mapping in order to collate, describe and catalog available evidence relating to the topic, allowing to address open-frame or closed-frame questions (James et al., 2016). Selection of articles was made with a decision tree (Figure 1), where the urban center, marine studies, and biodiversity approach had to be checked for any articles to be included. Fulfilling the requirement for inclusion, publications were classified in ecology in the city, ecology of the city or ecology for the city following the paradigms established by Pickett et al. (2016). Studies were counted just once for each paradigm. Gray-literature was not incorporated in the selection.

Each article collected was categorized by publication year, author's name, type of publication, author's affiliation country, study country, and study city. After examining each paper they were categorized according to disciplinary focus, study approach, type of analysis, main research object, study model, and coastal environment. A list of categories, their definitions and example references can be found in Table 1. Articles were classified by two of the authors independently. Results were then compared and discrepancies resolved with the participation of a third author. For each category, articles were counted just once.

City's population data were obtained from the United Nations (2019) compendium. Urban centers classification was modified from the United Nations (2014) and Barragán and de Andrés (2015). This classification includes: (1) Non-urban areas, which have $<100,000$ inhabitants, (2) small cities, between 100,000 and 500,000 inhabitants, (3) medium cities, between 500,000 and 1 


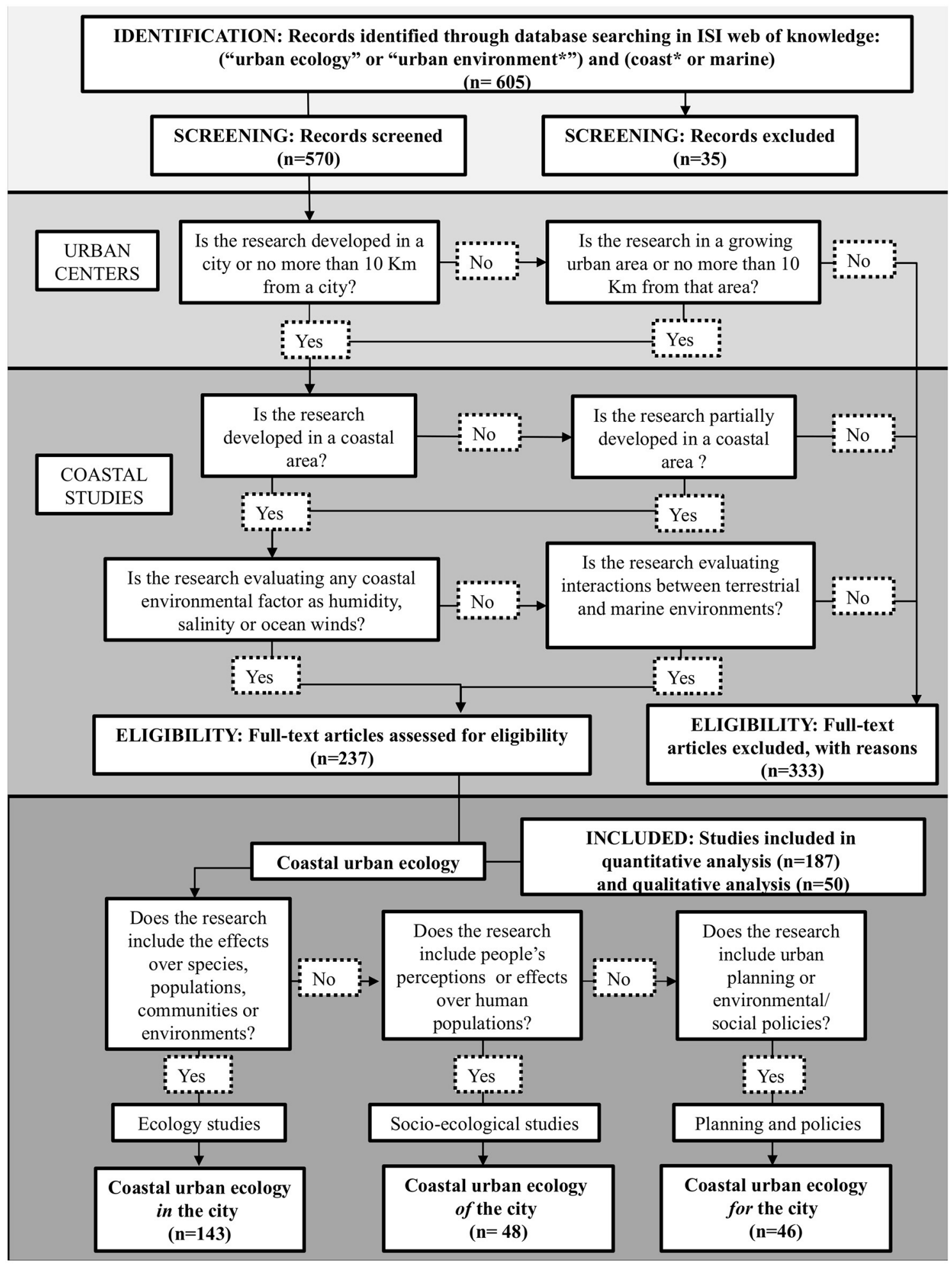

FIGURE 1 | Decision tree of articles selected based on a PRISMA flow diagram. Description of the selection process for articles in coastal urban ecology review. After four passes for selection filters, the remaining 237 studies where classified in three categories: urban ecological paradigms in, of, and for the cities. 
million, (4) large cities, between 1 and 5 million, (5) very large cities, between 5 and 10 million, and (6) megacities, with more than 10 million.

Characterization of articles according to urban ecology paradigms included the number of studies found for each paradigm, countries, year of publications, disciplinary focus, research approach, type of analysis, and main research objective. To examine the interaction among articles' paradigms, we analyzed the co-citations to other articles in our data base using the Web of Science database, and carried out a descriptive analysis of the network. We did not used topological measurements of the network, but rather describe its directionality. This analysis was developed with package bibliometrix (Aria and Cuccurullo, 2017), which allowed modifications in the code to create a new relationship between articles and their co-citations. The analysis included extracting every reference from each article that was selected in this review and the selection of cited articles that were already part of the article selection. Consequently, there was a tagging for each article cited with corresponding paradigm classification and these were plotted to unveil the relationship among paradigms used.

Classification, data analysis, and figures were prepared in R Core Team (2020) using RStudio Team (2019). For data analysis, packages tidyverse (Wickham et al., 2019a), dplyr (Wickham et al., 2019b), purrr (Henry and Wickham, 2017), broom (Robinson, 2014), and stringr (Wickham, 2019) were used. Graphs and maps were plotted with ggplot2 (Wickham, 2016) and gridextra (Auguie, 2016).

\section{RESULTS}

\section{Coastal Urban Ecology Tendencies}

Coastal urban ecology studies that met selection criteria included a total of 237 articles (Figure 1) from 51 countries, involving 137 different coastal cities. Most of the research was carried out in three countries: USA presenting 38 articles published, which included 20 different cities, China with 20 articles from 10 different cities, and Australia also with 20 articles, including 10 different cities (Figure 2). The timeline of publications shows that urban ecology in coasts appeared for the first time with Barcelona in 1979, however, it was not until 1995 that another study related to the field was published with Punda-Polic et al. (1995). Between 1995 and 2005, the number of publications was below five articles per year (Figure 3). After 2005 more articles can be found, particularly in years 2016, 2018, and 2019, which showed more than 20 publications per year. According to the type of publication found at the Web of Science database, publications are mostly journal articles with $84.97 \%$ of the total, proceedings papers represented 9.7\% (e.g., Kulkova et al., 2011; Giovene di Girasole, 2014; Fu et al., 2018), indexed book chapters $2.11 \%$ (e.g., Race et al., 2010; Wong, 2011; Juchimiuk and Januszkiewicz, 2019), and reviews 2.11\% (e.g., Garden et al., 2006; Cohen et al., 2013; Branoff, 2017).

General findings and tendencies since 1995 are shown in Figure 3. The main disciplinary focus of research has consistently come from ecology with an average representation of $48.79 \%$ of studies for the whole study period. Among ecological studies, those where coastal urbanization have modified ecological patterns stand out. For example Way et al. (2004), tracked movement and activity patterns of coyotes in northeastern North America, demonstrating that these mammals used more urbanized areas than natural ones. Other studies have assessed diets and feeding habitats of coastal birds to assess the interplay between natural and anthropogenic factors in determining diversity patterns (Washburn et al., 2013). Social-ecological studies were the second most common disciplinary focus with $24.47 \%$ (an average 2.2 publications per year between 2005 and 2009, 4.4 between 2010 and 2014, and 3.8 between 2015 and 2019; Figure 3). Social-ecological studies include those which focus on biodiversity and natural environment perceptions and human well-being. For instance, White et al. (2013) assessed human emotions toward different coastal environments and Burger et al. (2017) assessed human preferences toward protection and restoration. Environmental policy and planning studies have focused on developing guidelines for planning in order to contribute to the sustainability of the urban environment. For instance Alcoforado et al. (2009) identified climatic needs in a coastal city and discussed problems that arise when applying climatic knowledge to urban planning. Disciplinary focus of research showed high number of publications on traditional ecology, centered on how biodiversity patterns are affected by cities. However, despite noticeable exceptions, focus on human dimensions, such as studies which deal with perceptions and well-being associated to urban development and environmental footprint have received less attention. In addition multidisciplinary research on defining and designing solutions, associated to various forms of participatory approaches in order to move toward urban sustainability, are still scarce, showing a gap in knowledge.

Coastal ecology research has mainly considered spatial approaches searching for patterns based on differences in urban morphology. These spatial patterns include land cover and land use. For instance, research based on beach width and coastal slope that determine the most critical physical parameters to create coastal vulnerability maps (Kantamaneni et al., 2019). Study approaches have slowly included temporal dimensions (Figure 3). Spatio-temporal studies included articles such as Grossmann (2008) who discusses the consequences of current global technological, organizational and economic developments for a port. Temporal studies included Priestley et al. (2018) who assessed inorganic and organic compounds and their relation to photolysis and Martin et al. (2007) who studied management approaches for a coastal urban pest (White Ibis) along the east coast of Australia. Studies which use experimental approaches through time represent $<1 \%$ of the articles. They included articles such as the study of Leclerc and Viard (2018), who studied how swimming predators influenced the early development of fauna associated with floating pontoons in marinas. A significant higher number of publications considering spatial instead of temporal approaches could generate a static representation of what happens in coastal cities. This is particularly relevant in the face of climate change scenarios, where temporal variability becomes important. 
TABLE 1 | Classification of articles in coastal urban ecology.

\begin{tabular}{|c|c|c|}
\hline Category & Classification & Description \\
\hline \multirow[t]{5}{*}{ Disciplinary focus } & Ecological & $\begin{array}{l}\text { Study of relationships and interaction between organisms and } \\
\text { their coastal urban environment. }\end{array}$ \\
\hline & Social & $\begin{array}{l}\text { Study of social behavior, including its origin, evolution and } \\
\text { organization within a coastal urban environment. }\end{array}$ \\
\hline & Social-ecological & $\begin{array}{l}\text { Study of interaction between humans and their coastal urban } \\
\text { environment, using multidisciplinary approaches including } \\
\text { anthropology, geography, sociology and ecology. }\end{array}$ \\
\hline & Environmental policy & $\begin{array}{l}\text { Study of the environment with a focus in organization, law, } \\
\text { regulations or policy solutions. }\end{array}$ \\
\hline & Social policy & $\begin{array}{l}\text { Provides practical guidelines and principles to improve human } \\
\text { welfare. }\end{array}$ \\
\hline \multirow[t]{5}{*}{ Study approach } & Spatial & $\begin{array}{l}\text { Focus on landscape, land cover, or urban geomorphology } \\
\text { changes. }\end{array}$ \\
\hline & Spatiotemporal & $\begin{array}{l}\text { Landscape, land cover, or urban geomorphology changes, } \\
\text { including some changes over time on small scale. }\end{array}$ \\
\hline & Temporal & Focus in changes over time. \\
\hline & Temporal experiment & $\begin{array}{l}\text { Focus in changes over time in a controlled environments and } \\
\text { simulations. }\end{array}$ \\
\hline & Experimental & Including all lab procedures. \\
\hline \multirow[t]{3}{*}{ Type of analysis } & Qualitative analysis & Non-numerical descriptions and ethnographic studies. \\
\hline & Quantitative analysis & $\begin{array}{l}\text { Collection and evaluation of measurable data of either social } \\
\text { or environmental aspects. }\end{array}$ \\
\hline & Modeling studies & Mostly computational simulations. \\
\hline \multirow[t]{7}{*}{ Main research object } & City design & Mainly urban planning. \\
\hline & Demographic change & $\begin{array}{l}\text { Variation in the population in terms of size, average age, life } \\
\text { expectancy, family structures, or birth rates, among others. }\end{array}$ \\
\hline & Habitat use & Variation in the distribution of species within cities. \\
\hline & Human adaptation & $\begin{array}{l}\text { People's reaction to urban changes and creation of new } \\
\text { spaces }\end{array}$ \\
\hline & Natural disaster & $\begin{array}{l}\text { City's risks or damage associated to floods, hurricanes, } \\
\text { storms, tsunamis, or another geophysical process. }\end{array}$ \\
\hline & $\begin{array}{l}\text { Pollution and human } \\
\text { impacts }\end{array}$ & $\begin{array}{l}\text { Effects of city growth and/or increase in urbanization as a } \\
\text { measurement of contamination. }\end{array}$ \\
\hline & Shoreline changes & $\begin{array}{l}\text { New infrastructure in the shoreline, waterfronts and other } \\
\text { constructions. }\end{array}$ \\
\hline \multirow[t]{5}{*}{ Study model } & Physical & $\begin{array}{l}\text { Physical space comprises research with aerosol, } \\
\text { geomorphological elements, land structures, meteorological } \\
\text { elements, pollutants, remote sensing data, risk models, } \\
\text { seawater, surface deterioration, and water resources. }\end{array}$ \\
\hline & $\begin{array}{l}\text { Social-ecological- } \\
\text { technological. }\end{array}$ & $\begin{array}{l}\text { Includes marine and green structures, eco-cities, and } \\
\text { sustainable cities. }\end{array}$ \\
\hline & Social & $\begin{array}{l}\text { Social space comprises bioclimatic comfort, demographic, } \\
\text { human activities and culural heritage, perceptions, public } \\
\text { health, and sustainable development. }\end{array}$ \\
\hline & Biological-species & $\begin{array}{l}\text { Biological in terms of studied organisms or their parts, } \\
\text { including algae, antibiotics, bacteria, birds, fishes, } \\
\text { invertebrates, lichens, mammals, and plants. }\end{array}$ \\
\hline & Biological-ecosystems & $\begin{array}{l}\text { Biological in terms of studied ecosystems, including studies in } \\
\text { diversity, ecological processes and patterns, ecosystems, } \\
\text { and environmental management. }\end{array}$ \\
\hline \multirow[t]{5}{*}{ Study habitat } & Near-shore terrestrial & $\begin{array}{l}\text { Includes dunes, coastal xeromorphic habitats, rocky and } \\
\text { sandy shores, urban, agricultural and industrial landscapes in } \\
\text { the coast. }\end{array}$ \\
\hline & Intertidal & $\begin{array}{l}\text { Estuaries, deltas, mangrove forests, coastal lagoons, salt } \\
\text { marshes, other coastal wetlands, marinas and ports. }\end{array}$ \\
\hline & $\begin{array}{l}\text { Near-shore coastal } \\
\text { benthic }\end{array}$ & $\begin{array}{l}\text { Seagrass beds, artificial structures and soft bottom } \\
\text { environments above the continental shelf. }\end{array}$ \\
\hline & Coastal pelagic & Open waters above the continental shelf. \\
\hline & Coastal atmosphere & The aerial space. \\
\hline
\end{tabular}

Examples

Tait et al., 2005; Smith and Munro, 2010

Abarca-Álvarez et al., 2018

White et al., 2013; Burger et al., 2017

Alcoforado et al., 2009; Vye and Rousseaux, 2010

Jonkman et al., 2013; Guerrero Valdebenito and Alarcon Rodriguez, 2018

Garden et al., 2006; Yamazaki et al., 2007

Grossmann, 2008; Li et al., 2011

Semadeni-Davies et al., 2008; Yu et al., 2019

Chabas et al., 2015; Leclerc and Viard, 2018

Zhen et al., 2007; Charalambous et al., 2012

Gardner, 2003; Arif, 2017

Galimany et al., 2013; Branoff, 2017

Sahal et al., 2013; Santos and Freire, 2015

Alcoforado et al., 2009; Kantamaneni et al., 2019

Race et al., 2010, Abarca-Álvarez et al., 2018

Lim and Sodhi, 2004; Reyes-López and Carpintero, 2014

Weinstein, 2009; Chen et al., 2015

Yin et al., 2016; Su et al., 2019

Ip et al., 2007; Arruti et al., 2011

Wu, 2007; Alberico et al., 2018

Pollutants: Pallarés et al., 2019

Remote sensing: Peng et al., 2017

Marine structures: Gumusay et al., 2016

Eco-cities: Surjan and Shaw, 2008

Human activities and culural heritage: Cleland et al., 2015

Perceptions: Nunkoo and Ramkissoon, 2010

Birds: Belant, 1997

Fishes: Naidoo et al., 2016

Environmental management: Tu and Shi, 2006 Ecosystems: Branoff, 2017

Watson, 2015; Whisson et al., 2015

Jonkman et al., 2013; Kuwae et al., 2016

Eddy and Roman, 2016; Bolton et al., 2017

Zhen et al., 2007; Wang et al., 2010

Clarkson et al., 1996; Dominick et al., 2018 


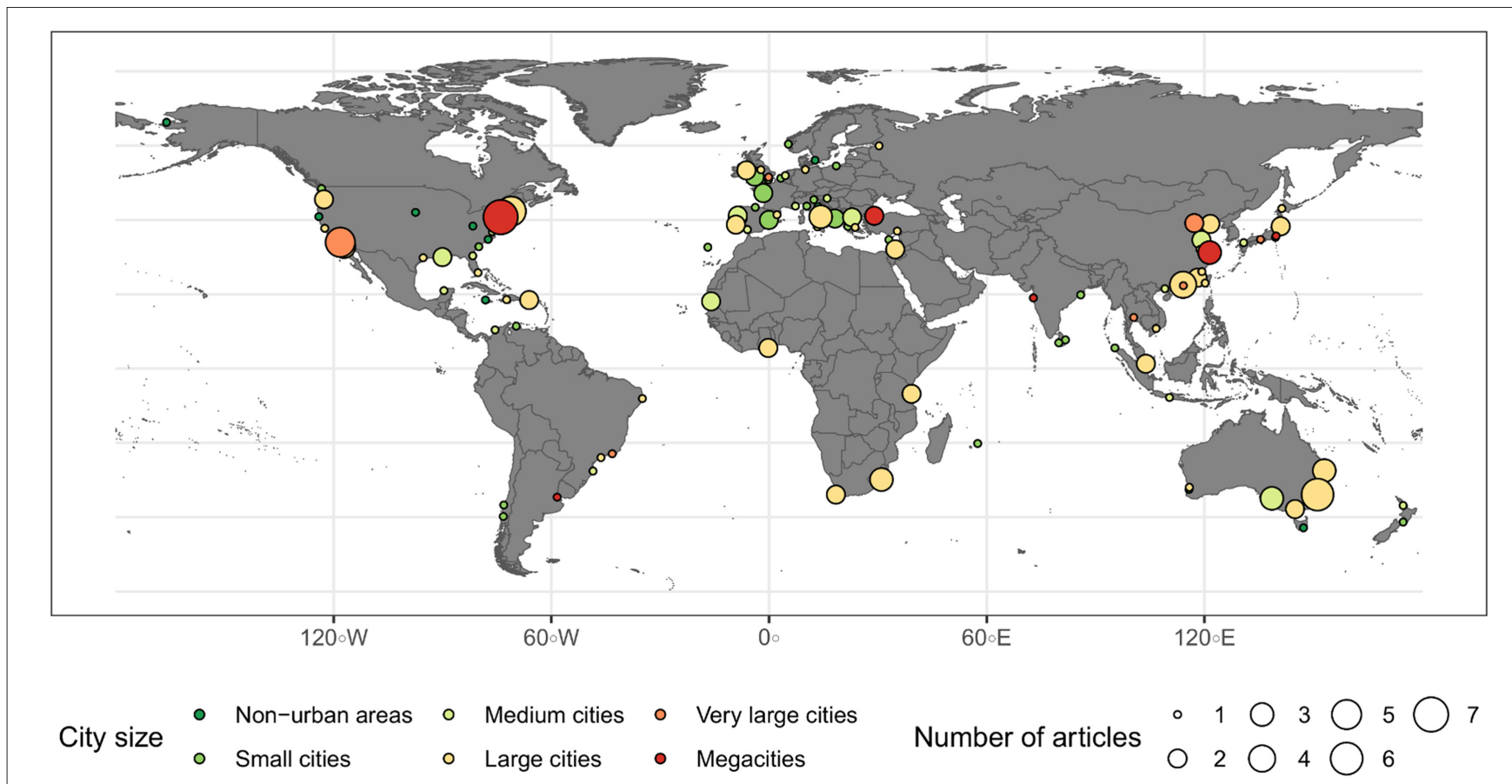

FIGURE 2 | Global distribution of publications. Articles in coastal urban ecology according to the city where the investigations were carried out, the population size of each city and the number of articles published in them. For each city the size of the circle is proportional to the number of articles published (from 1 to 7 ); the color of the circle represents the size of the city given its population.

Quantitative studies have dominated the literature during the past 20 years and have focused on ecological approaches. For example Tzortzakaki et al. (2018) studied the effect of the different land-cover types on bird species richness and abundance and concluded that open green spaces are the most significant factor favoring bird diversity in a coastal city in Greece. Qualitative studies represent 20\% of the articles. These mainly use a social-ecological approach. Studies use qualitative interviews to assess urban coastal environmental constructs and preferences (Cleland et al., 2015). Other qualitative studies have been used to design green infrastructure in urban cities (Chen et al., 2015). Policy studies such as Guerrero Valdebenito and Alarcon Rodriguez (2018) used qualitative approaches to assess tensions and threats to traditional small-scale artisanal fishers coexisting with larger urbanized systems such as mega infrastructures, ports and cities. Modeling studies which include simulation of urban conditions, have begun to emerge in the past 6 years (Figure 3) to address a wide variety of issues. For example, Stathopoulou and Cartalis (2007) modeled the thermal urban environment and urban heat island phenomenon in mayor urban areas in Greece. Su et al. (2019) used modeling to determine realistic flooding scenarios. Other modeling studies have contributed to assess social-ecological dimensions. Sahal et al. (2013) used macro-simulators and micro-simulators with multi-agent-based modeling to select shelter points and choose evacuation routes for future tsunamis. Song et al. (2016) modeled urban environmental benefits, such as green infrastructure, industrial upgrade, and environmental management, in China, testing social-economic and demographic variables. The use of modeling to inform environmental policies has been approached mainly through mapping and risk assessments. For instance, Storch and Downes (2011) quantified and mapped current and future city-wide flood risks, combining climate change scenarios with urban land use scenarios. A key finding is that qualitative research approaches have been underrepresented. This has important consequences especially when assessing how the general public engage with urbanization and its impacts in coastal zones. Accordingly, there are important gaps of knowledge in this area.

When looking at the main research objectives it is interesting to note that the study of pollution and human impacts have dominated the literature (Figure 3). These articles mainly focus on the effects of stressors over coastal urban ecosystems and cities. For instance, Jartun and Pettersen (2010) collected sediments from urban stormwater runoff and analyzed various contaminants, showing that several active pollution sources are supplying the runoff systems. Studies that focus on habitat use in urban areas are also common. For example, studies have focused on differences in communities between fixed and floating structures (Holloway and Connell, 2002) or on abundance and survival rates of charismatic species in highly industrialized bays (Eguchi et al., 2010). Studies which focus on different aspects of city design are less frequent, but they have been increasing in the last 10 years. Some of these studies have developed climatic guidelines for planning and identifying climatic needs in coastal cities (e.g Alcoforado et al., 2009), 


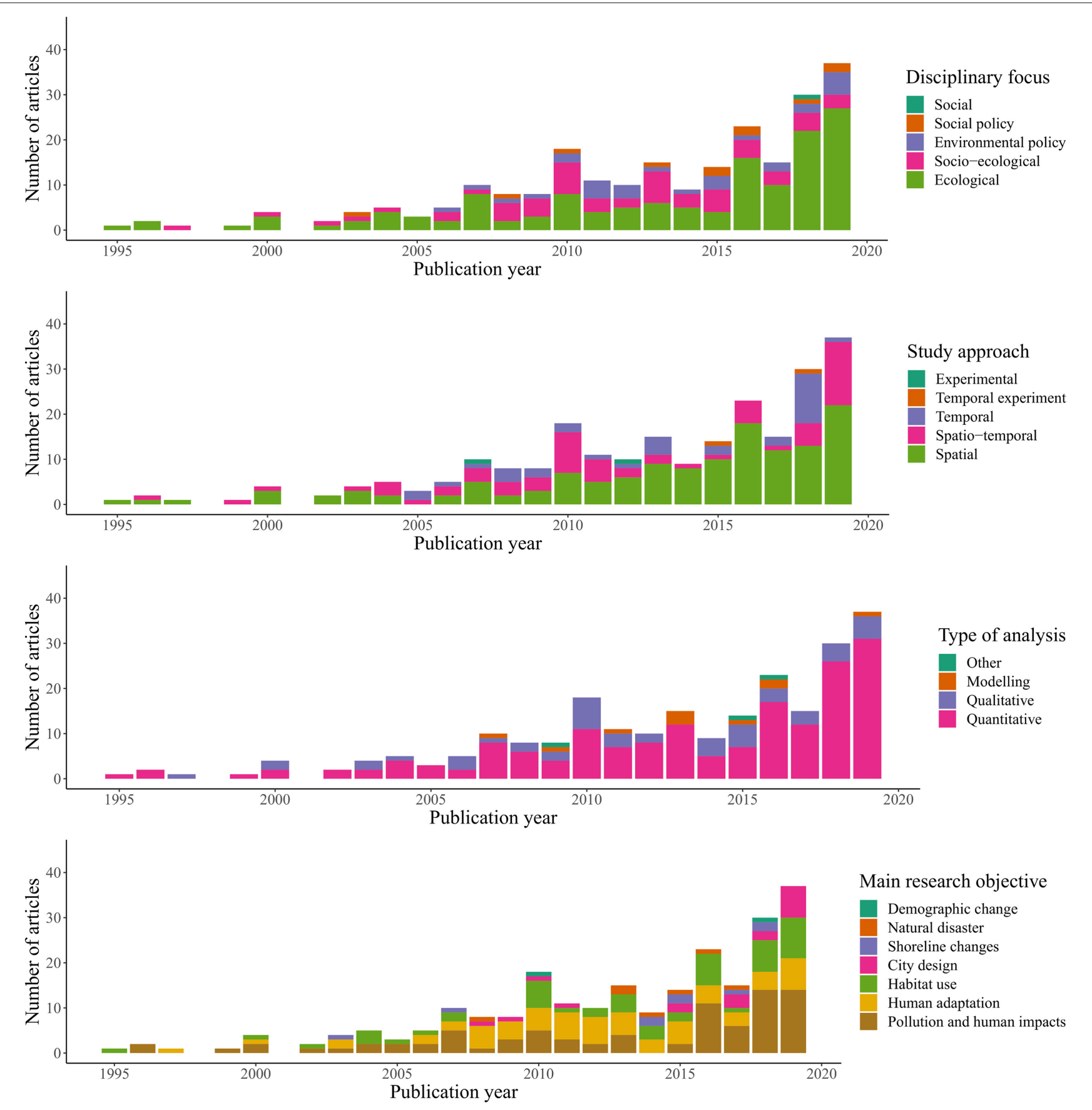

FIGURE 3 | Temporal distribution of categories. Articles in coastal urban ecology were categorized according to disciplinary focus, research approach, type of analysis, and main research objectives.

others have applied multi-criteria decision analysis to explore local stakeholders' perceptions in terms of priority actions for waterfront development (Papatheochari and Coccossis, 2019).

According to study models used (Figure 4), a significant number of publications focused on physical aspects (48.10\%) such as pollutants and risk toward natural hazards (Buggy and Tobin, 2008; Dominick et al., 2018). The second most frequent study model was biological, centered on specific species (21.94\%). In this group, birds were the most studied (e.g., Kalinowski and Johnson, 2010, studying a suburban bird community; SainzBorgo et al., 2016, studying the house sparrow; Blight et al., 2019, studying an urban-nesting gull population). Invertebrates were the second most studied group including marine (Galimany et al., 2013; Eddy and Roman, 2016); and terrestrial species (Bizzo et al., 


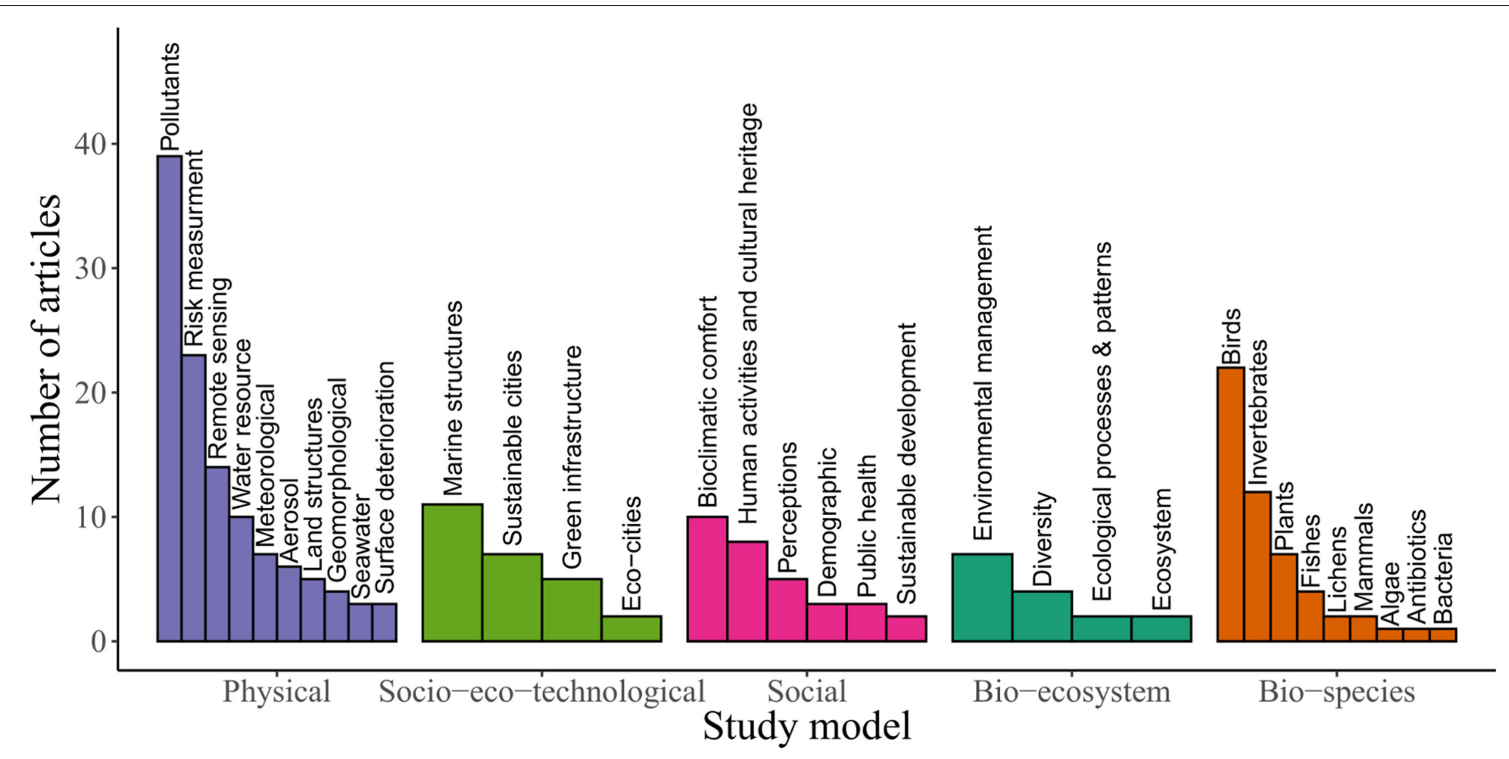

FIGURE 4 | Distribution of articles, according to study models of research. Coastal urban ecology models were grouped by Physical, Social-Ecological-Technological, Social, Biological-Ecosystem, and Biological-species.

2010; Reyes-López and Carpintero, 2014). While other marine species such as fishes received less attention, some noticeable examples include the study by Bolton et al. (2017) of fish communities. Studies centered on specific ecosystems (Ehrenfeld, 2000; Branoff, 2017) or social-eco-technological systems showed $<10$ articles published. Foremost among these are those on eco-cities (e.g., Wong, 2011). This evidence indicates that study models have been frequently replicated. The dominance of certain study models has allowed progress in the field on certain issues. But at the same time, there are some fields that have not progressed at all such as those that include organisms like algae or marine microorganism.

Most of the articles published in coastal urban ecology have been developed in large cities of 1 to 5 million inhabitants (41\%), while other city categories do not exceed $18 \%$. More than $55 \%$ of articles were carried out in cities with more than 1 million people, including very large cities such as Los Angeles in USA (Barcelona, 1979), Osaka in Japan (Yamazaki et al., 2007), Tianjin in China (Peng et al., 2011), Bangkok in Thailand (Burnett et al., 2007), and megacities with more than 10 million people such as Shanghai in China (Li et al., 2018), Tokyo in Japan (Krishnan et al., 2019), New York in USA (Washburn et al., 2013), Buenos Aires in Argentina (Cardo et al., 2014). Coastal areas with $<100,000$ inhabitants presented only $10 \%$ of articles. These are dominated by articles from the USA (e.g., Kalinowski and Johnson, 2010; Wolsko and Marino, 2016). There is a clear focus on large cities and important knowledge gaps remain in studying urbanization processes and differences associated to growth of smaller cities and the social-ecological complexities they confront.

Research in coastal urban ecology has focused mostly in nearshore terrestrial environments, presenting more than $68 \%$ of articles. These have focused on urban environments (e.g., Parzych et al., 2016), anthropogenic constructions (Günel, 2018), green areas (Callaghan et al., 2018), and urban watersheads (Pinheiro and Hokugo, 2019). Intertidal areas presented $17.30 \%$ of the publications. Some of these focused on coastal defenses (e.g., Jonkman et al., 2013), estuarine and shallow coastal systems (Kuwae et al., 2016), estuarine mullet in an urban harbor (Naidoo et al., 2016) and predation on a threatened coastal seabird (Greenwell et al., 2019). Near-shore coastal benthic habitats accounted for $3.38 \%$ and included studies such as those which assess community structure (e.g., Holloway and Connell, 2002; Eddy and Roman, 2016), impacts of light on communities (Bolton et al., 2017) and spatial distribution patterns [e.g., Heery et al., 2018 for the giant Pacific octopus (Enteroctopus dofleini)]. Studies which focus on pelagic environments near the coast account for only $1.69 \%$. These relate mostly to sea water studies such as Zhen et al. (2007) and ocean thermal energy (Wang et al., 2010). Coastal atmosphere showed $8.86 \%$ of total articles published (e.g., aerosol: Castro et al., 1999; PM10 pollution episodes: Vicente et al., 2012; atmospheric deposition: Shanquan et al., 2016; and chemical composition of fine-aerosol fraction: Theodosi et al., 2018).

Current research evidence suggests studies in coastal urban systems deal greatly with pollutants and ecological implications, with emerging interests in planning and social interactions and responses. The ways in which these areas interact in time and space and across different city sizes and configurations could provide to be particularly novel research endeavors. Important issues such as the environmental footprint and social-ecological tradeoffs of coastal configurations of few large or a series of smaller cities settled along the coast are some key areas which need further development (Weinstein, 2009; Kaniewski et al., 2013; Barragán and de Andrés, 2015). Ultimately, coastal urban ecology still has important research opportunities in addressing the interactive effects of urban 

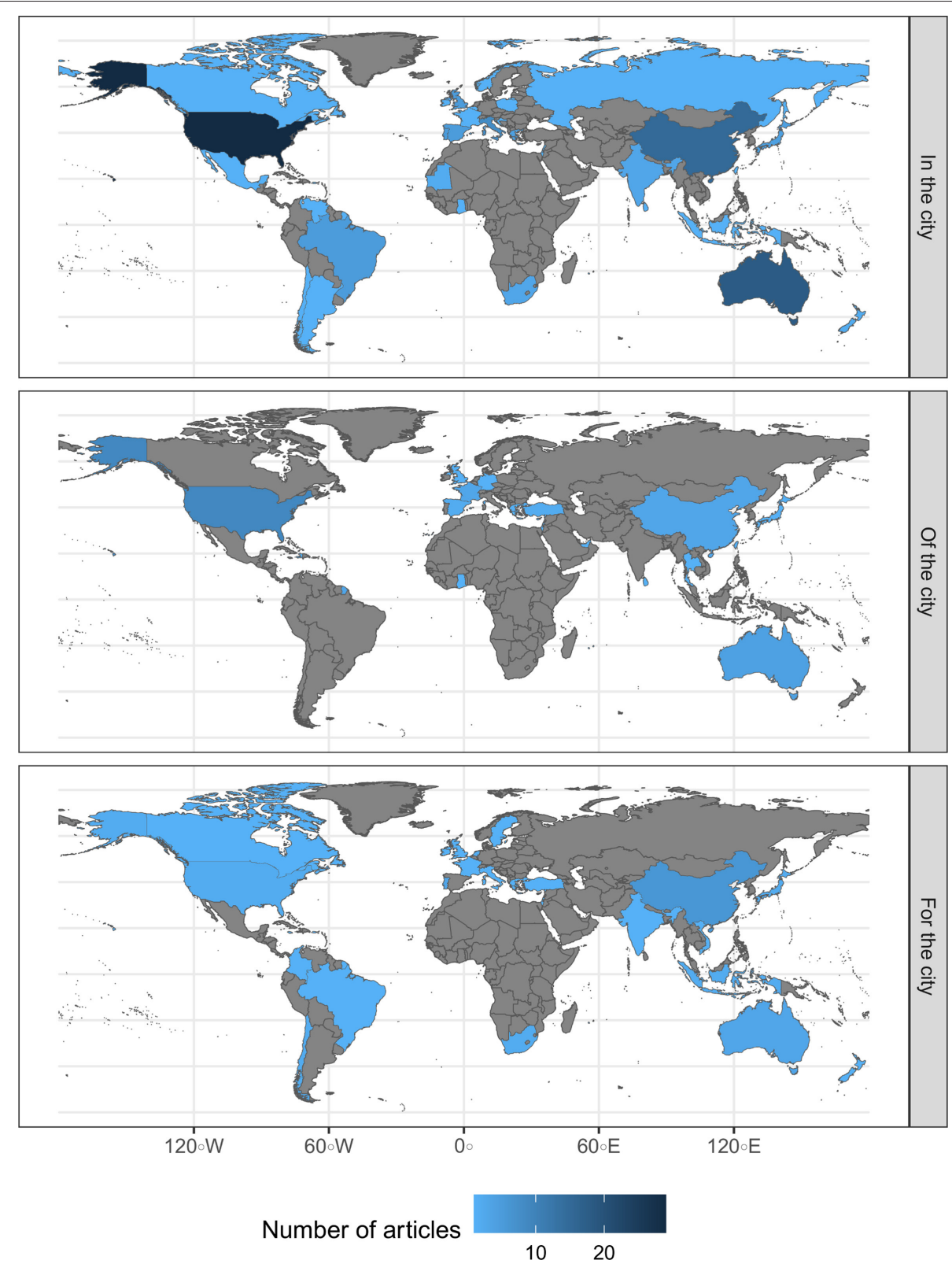

FIGURE 5 | Contribution of countries by paradigms. Coastal urban ecology studies ascribed to Picketts's paradigms in, of, and for the city (presented in blue colors from light to dark); Countries that not present coastal urban ecological articles are show in gray.

drivers, social-ecological responses and how planning processes accommodate these complex system dynamics.

\section{Coastal Urban Ecology in, of, and for the City}

Paradigms in, of, and for the city have been addressed globally (Figure 5). The focus in the city is represented in more than $60 \%$ of articles, including 37 countries. The US showed the highest number of articles with 29 publications (e.g., Way et al., 2004; Eddy and Roman, 2016; Maguire and Fulweiler, 2019). The focus of the city is shown at a lower percentage than the previous paradigm, with $20.25 \%$ of publications and performed in 21 countries. The US also dominated this paradigm with 9 articles (e.g., Gasper et al., 2011; Douglas et al., 2012; Burger et al., 2017). Research addressing the for the city paradigm represented $19.41 \%$ of total articles and came from 25 different countries. China presents six articles (e.g., Li et al., 2011, 2017; Peng et al., 2011), which is the highest number of papers in a country which addresses this paradigm. This result indicates that coastal urban ecology is dominated by research with a focus in the city and only few countries have attended to develop the three paradigms.

Paradigms in, of, and for the cities have shown differences, not only in the total number of articles published (143, 48, and 46 , respectively) but also in their first year of publishing and 


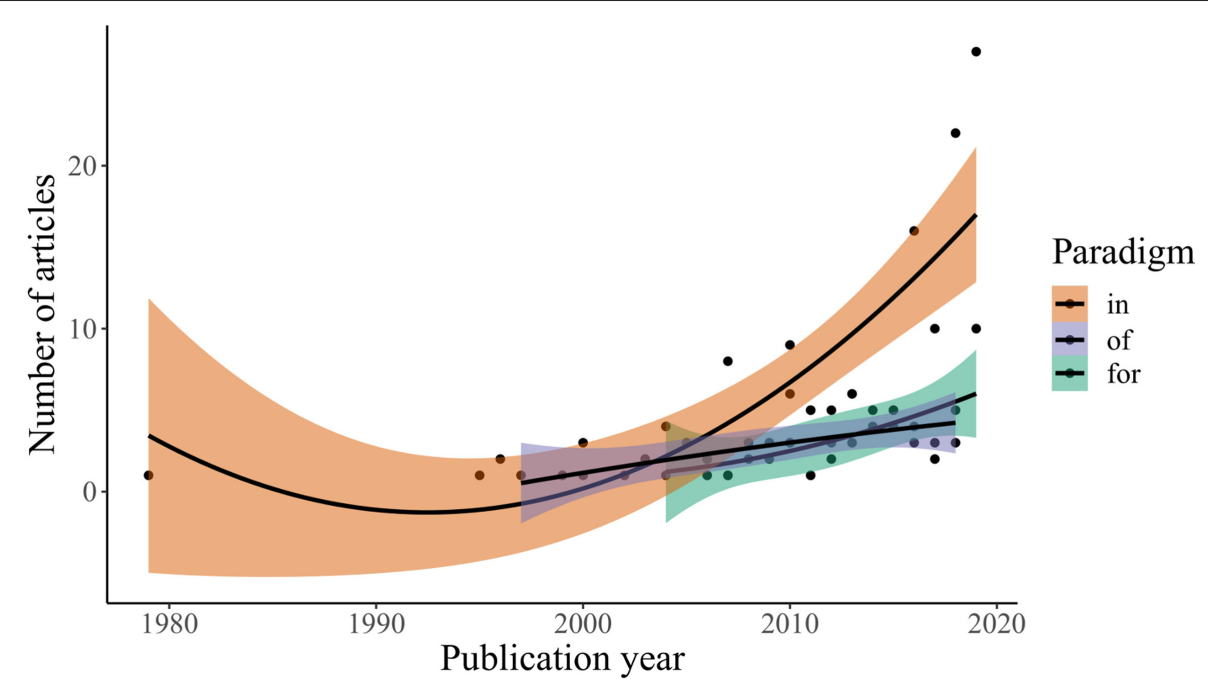

FIGURE 6 | Paradigms' temporal changes. Number of articles published considering paradigms in, of, and for the cities. Trend lines represent quadratic regression fit (in the city $\mathrm{R}^{2}=0.656, p<0.001$, of the city $\mathrm{R}^{2}=0.382, p<0.05$, for the city $\mathrm{R}^{2}=0.460, p<0.05$ ); color areas represent the $95 \%$ confidence interval.

subsequent tendencies (Figure 6). In this way, it is not until 2004 that the paradigm for the city appeared in coastal urban ecology studies (Patz et al., 2004). Before that, the paradigm in the city (since the beginning with Barcelona, 1979) dominated this research area, with some occurrence of the paradigm of the city since 1997 (Belant, 1997). The three paradigms show to be increasing in the number of publications during the last decade, although the paradigm in the city is doing it faster than the others. This could result in an even larger gap between the number of publications focused on each paradigm.

Evidence suggests that the three paradigms are different according to disciplinary focus, research approach, type of analysis, and the main research objectives presented in their articles (Figure 7). As expected, categorization by discipline showed that the paradigm in the city is mostly focused in ecological research, the paradigm of the city in social-ecological research, and paradigm for the city in environmental policies, and also some social-ecological and social policies. Research approaches are similar among paradigms, the spatial approach of studies is the most common (e.g., ecology in the city: Hosannah and Gonzalez, 2014; ecology of the city: Bulleri, 2006; ecology for the city: Santos and Freire, 2015), followed by spatio-temporal approach (e.g., ecology in the city: Castro et al., 1999; ecology of the city: Serre et al., 2010; ecology for the city: Storch and Downes 2011). Experiments and the interplay with temporal approaches are poorly represented in coastal urban ecology studies. Studies in the city presented mostly quantitative assessments, however, studies presented under paradigms of and for the city showed similar proportions between quantitative and qualitative analysis. The paradigm of the city has centered research on themes related to human adaptation (e.g., Wolsko and Marino, 2016, integrated research on disasters and climate change-induced migration with environmental psychology and the psychology of natural disasters), this topic also appears in the paradigm for the city in combination with city design, a consequence of the predominant focus on policy and planning implications of these studies. An example of human adaptations can be found in Villagra et al. (2016) who described the "resilience thinking" approach in urban planning, in order for a coastal city to adapt to extreme natural events such as tsunamis. Also, Conticelli and Tondelli (2018) proposed an urban regeneration of a coastal territory considering the local coastal landscape as a key element for boosting local sustainable growth.

When analyzing the whole database of coastal urban ecology articles, only 34 publications showed connections among citations, presenting a total of 24 interactions (Figure 8). These interactions varied in strength from one article citing a single article of the one included in our study, two cited the same article (Lopes et al., 2011; Chen et al., 2018), three cited the same article (Campbell, 2010; Washburn et al., 2013; Shepard et al., 2016), or four cited the same article (Campbell, 2010; Bertocci et al., 2017; Heery et al., 2018; Leclerc and Viard, 2018; Bugnot et al., 2019). Network analysis showed a marginal interaction among articles' paradigms. Here the paradigm in the city cited only seven in the city articles from a total of 16 citations, the paradigm of the city cited three articles in the city and one of the city from a total of seven citations, paradigm for the city cited only one article under the paradigm of the city. These results suggest that coastal urban ecology article citation have a subtle connection among publications, and it is not reinforced when the three paradigms are considered.

\section{DISCUSSION}

Coastal urban ecology encompasses a diversity of disciplines and research models aimed at understanding the links between the natural and built environments. Results show that coastal urban ecology has focused primarily on ecological studies and 


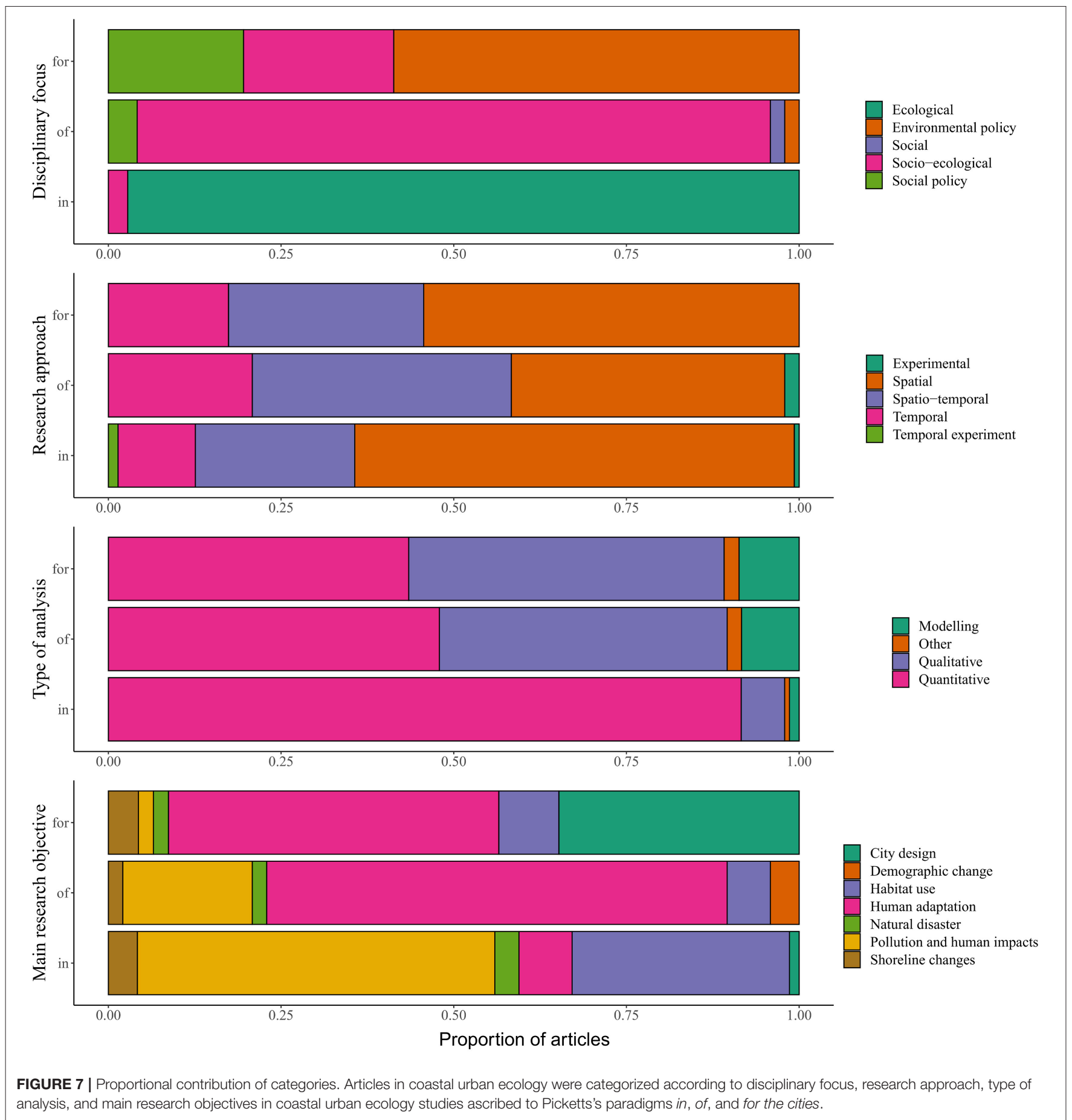

those studying physical characteristics of urban centers in coastal areas, dominated by research on pollution. However, there is an increasing contribution of studies on social dimensions. Studies that address coastal urban ecology from an in the city perspective have significantly increased during the last three decades. Interestingly, results show that coastal urban ecology is beginning to address issues which relate to planners and policy makers through some key studies on green infrastructure (Zhang et al., 2014; Chen et al., 2015), eco-cities (Surjan and Shaw, 2008; Wong, 2011), and sustainable cities (Pizarro, 2008; Song et al., 2016; Arif, 2017). Despite the diversity of research on coastal urban ecology, there are still important geographic and disciplinary gaps in research foci.

Coastal urban ecology research has drawn from ecological studies more than any other discipline (Figure 3). Even when it seems that social dimensions have been integrated slowly 


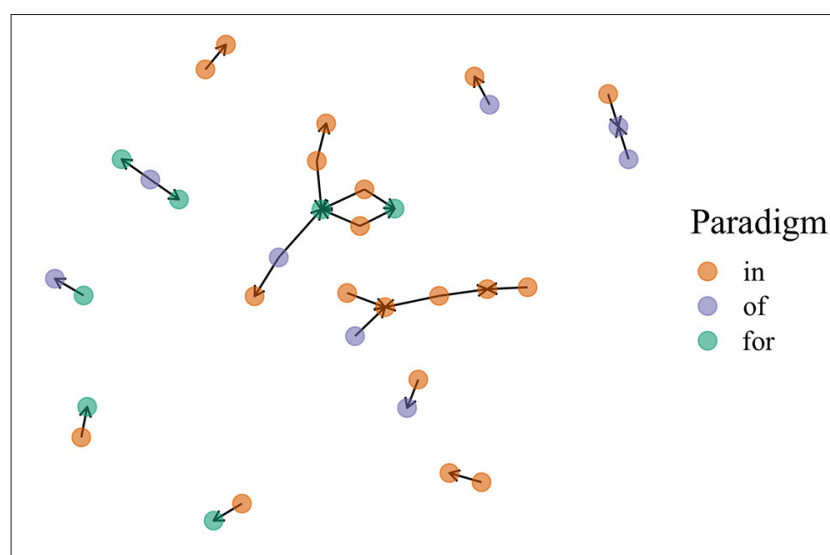

FIGURE 8 | Network analysis. Analysis for co-citations of articles presented in this coastal urban ecology review, considering the three paradigms proposed. Each dot represents a study and the color indicates the paradigms (in, of, and for the cities). Directed edges go from the article citing to the article being cited.

during the years under the knowledge of human-nature coupling (Liu et al., 2007a,b) and the importance to include people and their relationship with the urban environment (Redman et al., 2004), interdisciplinary studies are still infrequent. An interesting interdisciplinary line of research is emerging associated with designing new infrastructures in coastal cities aimed at the provision of sustainable alternatives as new habitats for protection and even promotion of biodiversity (Kates et al., 2001; Perkol-Finkel et al., 2018; Burt and Bartholomew, 2019). However, these interdisciplinary efforts have been performed in a few coastal areas (Morris et al., 2019), showing similar geographical bias.

Coastal urban ecology has centered mainly in understanding spatial patterns and variability, showing a bias toward short time scale research (Figure 3). Consequently, there is a shortfall in long-term dynamic perspectives in the study of coastal cities. Results demonstrate research is also biased toward quantitative approaches with few qualitative analyses (e.g., Giovene di Girasole, 2014; Cleland et al., 2015; Villagra et al., 2016; Guerrero Valdebenito and Alarcon Rodriguez, 2018). This supports the results which show little social science research based on methods such as grounded theory or ethnography, among others (Creswell et al., 2007). Coastal urban ecology would benefit from encouraging these long-term and disciplinary dimensions.

Many coastal urban ecology studies focus on pollutants. The focus on pollution has been maintained during the whole period analyzed, with $35 \%$ of total articles dealing with this issue. Accordingly, the effects of urbanization over sea breeze and the reactions of aerosols have had an important increase in this line of research (Castro et al., 1999; Mejia and Morawska, 2009; Shanquan et al., 2016; Pushpawela et al., 2018). A predominant focus on pollution is not difficult to understand in coastal urban ecology given urbanization and increases in $\mathrm{CO}_{2}$ emissions (Cole and Neumayer, 2004). Water pollution also has an important number of articles published $(27.7 \%$ from the total of articles that mentioned pollution), considering marine (23 articles: e.g., Noble et al., 2006; Wang et al., 2010) and river basin pollution (four articles: e.g., Abdul-Aziz and Ahmed, 2019; Mgelwa et al., 2019), both important elements in coastal environments.

Risk assessments toward natural disasters and particularly flooding represented approximately $18 \%$ of the studies (Figure 4; e.g., Goh, 2019; Patel et al., 2019), which were carried out mainly in the USA and Japan. Expansion of coastal cities undermine natural protection (Sherbinin et al., 2007), hence an increase in natural disasters and city's vulnerability (Chang and Huang, 2015). While research has been performed in developed countries, developing ones are the most vulnerable in terms of natural disasters in coastal zones, such as flooding events (Ogie et al., 2020) or in specific areas under risk of tsunamis (Villagra et al., 2016). This same tendency is repeated in relation to studies which address mitigation strategies, with projections to make cities more resilient to natural disasters (Serre et al., 2010; Watson and Adams, 2010; Aerts et al., 2014; Sutton-Grier et al., 2015; Morris et al., 2020) and even ecoengineered shoreline strategies as nature-based alternative design (Bergen et al., 2001; Mitsch, 2012; Morris et al., 2019; O'Shaughnessy et al., 2020). As a consequence, there is an urgent need to extend this type of research toward developing and mid-income countries.

Our review shows that research on coastal urban ecology has mainly focused in cities between 1 and 5 million people in 15 different countries. However, more than a half of articles have been performed in the USA, China and Australia (Figure 2). While results from these specific studies can be important to develop theoretical frameworks and assess specific impacts, the focus on these high GDP countries makes it hard to extend insights to other cities in developing and mid-income countries, where growth dynamics, institutional support and adaptive capacity are very different (Chauvin et al., 2017; Nagendra et al., 2018). For example, urban concentration (when country resources are over-concentrated in one or two large cities, raising cost of production of goods) is described as part of country development, and decreases as income rises (Davis and Henderson, 2003). This phenomenon is often presented in coastal cities, where there is a physical infrastructure capital. Urban concentration can be affected significantly by a range of political variables, including democratization, federalism, and whether a country was a former planned economy (Davis and Henderson, 2003). We therefore strongly advocate for the need to support programs for coastal urban ecology research in these settings. Research in cities smaller than 1 million inhabitants would extend the variety of conditions in terms of the size of the human group, transitioning to bigger cities, and configuration of environmental variables, considering by 2017 more than $60 \%$ of cities in the world have between 100,000 and 1 million inhabitants (United Nations, 2019, data compilation).

Research has been mainly performed in near-shore terrestrial environments, resulting in a lack of information in coastalmarine urban environments that reveals the limited integration in the coastal urban interface (seawater-land configuration and dimensionality). This bias can have negative consequences such as generating false dichotomies for conservation, where marine and terrestrial ecosystems could meet as two isolated systems (Bulleri, 2006), which can undermine the effectiveness and 
need for healthy marine ecosystems in urban areas (Bulleri, 2006; Shochat et al., 2006). It is key to extend research on the interaction between marine and terrestrial realms associated with urbanization.

Results show that more than half of the reviewed articles can be classified as belonging to the paradigm in the cities. Studies contributing to this paradigm have been growing in number, faster than the others, during the last years (Figure 6). This result synthesizes the main biases found in this review which relate to the predominant focus on ecological research, understanding urban impacts such as pollution, the non-human components, and in spatial and quantitative analysis (Figure 7). Only $20 \%$ of the articles in coastal urban ecology focused on interdisciplinary research such as social-ecological studies (included in the paradigm of the city). This represents an important research gap associated to the lack of social knowledge in a system where humans are both objects and subjects of urbanization, who use space to live, extract subsistence and non-subsistence resources, perform recreational activities, and deposit waste, among other activities (Weinstein, 2009). Because of that, a lack of research on people with nature represents the loss of understanding an integral part of the ecosystem (McDonnell et al., 1993; Rees, 1997; Collins et al., 2000), decoupling human dynamics and ecological processes of this urban ecosystem (Alberti, 2008). Lessons from urban ecology in other systems have shown the importance of transitioning toward these interdisciplinary dimensions. Accordingly, coastal research in urban areas must advance toward an urban sustainability-centered perspective, transdisciplinary in terms of focuses and approaches, with the ability to inform urban design and planning ( $\mathrm{Wu}, 2014)$. Current imbalance among paradigms and the lack of interaction among research paradigms (Figure 8) can undermine urban coastal sustainability. Under Pickett's complexity of paradigms (Pickett et al., 2016), ecology for the city should include the knowledge generated by both ecology in and ecology of the city. In order to understand coastal urban ecological systems, coastal urban ecological paradigms need to build upon literature from each other.

While biophysical and ecological approaches to coastal urban systems are important, urban ecology necessarily operates in

\section{REFERENCES}

Abarca-Álvarez, F. J., Campos-Sánchez, F. S., and Reinoso-Bellido, R. (2018). Signs of gentrification usin g Artificial Intelligence: identification through the Dwelling Census. Bitác. Urban. Territ. 28, 103-114. doi: 10.15446/bitacora.v28n2.70145

Abdul-Aziz, O. I., and Ahmed, S. (2019). Evaluating the emergent controls of stream water quality with similitude and dimensionless numbers. J. Hydrol. Eng. 24:04019010. doi: 10.1061/(ASCE)HE.1943-5584.0001769

Aerts, J. C., Botzen, W. W., Emanuel, K., Lin, N., De Moel, H., and Michel-Kerjan, E. O. (2014). Evaluating flood resilience strategies for coastal megacities. Science 344, 473-475. doi: 10.1126/science.1248222

Alberico, I., Cavuoto, G., Di Fiore, V., Punzo, M., Tarallo, D., Pelosi, N., et al. (2018). Historical maps and satellite images as tools for shoreline variations and territorial changes assessment: the case study of Volturno Coastal Plain (Southern Italy). J. Coastal Conserv. 22, 919-937. doi: $10.1007 / \mathrm{s} 11852-017-0573-\mathrm{x}$ a human context. Results highlight the need for coastal cities to be seen from the point of view of people, their interaction with the environment and the implementation of concepts that contribute to sustainability in cities through public policies and planning. Developing regional learning platforms to address these dimensions should be a priority. Results of this review also recommend research needs to focus on the three paradigms equally. In addition, better consideration of the diversity of cities, the integration across marine and terrestrial ecosystems, and the inclusion of developing country coastal urban areas will allow to support ongoing urbanization trends and cultural settings in coastal zones across the globe. Clear research agendas that include trans-disciplinary collaborations will provide the opportunity to fill these knowledge gaps.

\section{DATA AVAILABILITY STATEMENT}

The datasets presented in this study can be found in online repositories. The names of the repository/repositories and accession number(s) can be found below: https:/github.com/ GiorgiaGraells/CoastalReviewGit.

\section{AUTHOR CONTRIBUTIONS}

GG and SG contributed to design of the study. GG and NN organized the database. GG performed the statistical analysis and wrote the first draft of the manuscript. SG, NN, JLC-D, NAL, PP, and PAM wrote sections of the manuscript. All authors contributed to conception and manuscript revision, read, and approved the submitted version.

\section{FUNDING}

This work was supported by the National Agency for Research and Development (ANID) Scholarship Program, National graduate scholarship [21171829, 2017], ANID-Millennium Science Initiative Program [Code ICN2019_015], Center of Applied Ecology and Sustainability (CAPES) [ANID PIA/BASAL FB0002], and Fondecyt 1190109. 
Arns, A., Dangendorf, S., Jensen, J., Talke, S., Bender, J., and Pattiaratchi, C. (2017). Sea-level rise induced amplification of coastal protection design heights. Scient. Rep. 7, 1-9. doi: 10.1038/srep40171

Arruti, A., Fernández-Olmo, I., and Irabien, A. (2011). Regional evaluation of particulate matter composition in an Atlantic coastal area (Cantabria region, northern Spain): Spatial variations in different urban and rural environments. Atmosph. Res. 101, 280-293. doi: 10.1016/j.atmosres.2011.03.001

Auguie, B. (2016). GridExtra: Miscellaneous Functions for "Grid" Graphics. Available online at: https://CRAN.R-project.org/package=gridExtra (accessed May 4, 2021).

Barcelona, M. J. (1979). Human exposure to chloroform in a coastal urban environment. J. Environ. Sci. Health Part A. 14, 267-283. doi: $10.1080 / 10934527909374879$

Barragán, J. M., and de Andrés, M. (2015). Analysis and trends of the world's coastal cities and agglomerations. Ocean Coastal Manag. 114, 11-20. doi: 10.1016/j.ocecoaman.2015.06.004

Barthel, S., Folke, C., and Colding, J. (2010). Social-ecological memory in urban gardens-Retaining the capacity for management of ecosystem services. Global Environ. Change. 20, 255-265. doi: 10.1016/j.gloenvcha.2010.01.001

Belant, J. L. (1997). Gulls in urban environments: landscape-level management to reduce conflict. Landscape Urban Plan. 38, 245-258. doi: 10.1016/S0169-2046(97)00037-6

Benveniste, J., Cazenave, A., Vignudelli, S., Fenoglio-Marc, L., Shah, R., Almar, R., et al. (2019). Requirements for a coastal hazards observing system. Front. Mar. Sci. 6:348. doi: $10.3389 /$ fmars.2019.00348

Bergen, S. D., Bolton, S. M., and Fridley, J. L. (2001). Design principles for ecological engineering. Ecol. Eng. 18, 201-210. doi: $10.1016 /$ S0925-8574(01)00078-7

Bertocci, I., Arenas, F., Cacabelos, E., Martins, G. M., Seabra, M. I., Álvaro, N. V., et al. (2017). Nowhere safe? Exploring the influence of urbanization across mainland and insular seashores in continental Portugal and the Azorean Archipelago. Mar. Pollut. Bull. 114, 644-655. doi: 10.1016/j.marpolbul.2016.10.045

Bizzo, L., Gottschalk, M. S., Toni, D. C. D., and Hofmann, P. R. (2010). Seasonal dynamics of a drosophilid (Diptera) assemblage and its potencial as bioindicator in open environments. Iheringia. Série Zool. 100, 185-191. doi: $10.1590 / S 0073-47212010000300001$

Blair, R. B. (1996). Land use and avian species diversity along an urban gradient. Ecol. Appl. 6, 506-519. doi: 10.2307/2269387

Blight, L. K., Bertram, D. F., and Kroc, E. (2019). Evaluating UAVbased techniques to census an urban-nesting gull population on Canada's Pacific coast. J. Unmanned Vehicle Sys. 7, 312-324. doi: 10.1139/juvs2019-0005

Bolton, D., Mayer-Pinto, M., Clark, G. F., Dafforn, K. A., Brassil, W. A., Becker, A., et al. (2017). Coastal urban lighting has ecological consequences for multiple trophic levels under the sea. Sci. Total Environ. 576, 1-9. doi: 10.1016/j.scitotenv.2016.10.037

Bolund, P., and Hunhammar, S. (1999). Ecosystem services in urban areas. Ecol. Eco. 29, 293-301. doi: 10.1016/S0921-8009(99)00013-0

Branoff, B. L. (2017). Quantifying the influence of urban land use on mangrove biology and ecology: a meta-analysis. Global Ecol. Biogeogr. 26, 1339-1356. doi: $10.1111 /$ geb.12638

Buggy, C. J., and Tobin, J. M. (2008). Seasonal and spatial distribution of metals in surface sediment of an urban estuary. Enviro. Poll. 155, 308-319. doi: 10.1016/j.envpol.2007.11.032

Bugnot, A. B., Hose, G. C., Walsh, C. J., Floerl, O., French, K., Dafforn, K. A., et al. (2019). Urban impacts across realms: making the case for inter-realm monitoring and management. Sci. Total Environ. 648, 711-719. doi: $10.1016 /$ j.scitotenv.2018.08.134

Bulleri, F. (2006). Is it time for urban ecology to include the marine realm? Trends Ecol. Evolut. 21, 658-659. doi: 10.1016/j.tree.2006.09.004

Burger, J., Tsipoura, N., Simnor, A., Pittfield, T., Jeitner, C., Mizrahi, D., et al. (2017). Perceptions of Caucasian users about avian resources and beach restoration following hurricane Sandy. Urban Ecosyst. 20, 363-373. doi: 10.1007/s11252-016-0598-1

Burnett, W. C., Wattayakorn, G., Taniguchi, M., Dulaiova, H., Sojisuporn, P., Rungsupa, S., et al. (2007). Groundwater-derived nutrient inputs to the Upper Gulf of Thailand. Conti. Shelf Res. 27, 176-190. doi: 10.1016/j.csr.2006.09.006
Burt, J. A., and Bartholomew, A. (2019). Towards more sustainable coastal development in the Arabian Gulf: Opportunities for ecological engineering in an urbanized seascape. Mar. Pollut. Bull. 142, 93-102. doi: 10.1016/j.marpolbul.2019.03.024

Cadenasso, M. L., Pickett, S. T., and Grove, M. J. (2006). Integrative approaches to investigating human-natural systems: the Baltimore ecosystem study. Nat. Sci. Soc. 14, 4-14. doi: 10.1051/nss:2006002

Callaghan, C. T., Major, R. E., Lyons, M. B., Martin, J. M., and Kingsford, R. T. (2018). The effects of local and landscape habitat attributes on bird diversity in urban greenspaces. Ecosphere 9:e02347. doi: 10.1002/ecs2.2347

Campbell, M. (2010). An animal geography of avian foraging competition on the Sussex coast of England. J. Coastal Res. 26, 44-52. doi: 10.2112/08-1087.1

Cardo, M. V., Vezzani, D., Rubio, A., and Carbajo, A. E. (2014). Integrating demographic and meteorological data in urban ecology: a case study of container-breeding mosquitoes in temperate Argentina. Area 46, 18-26. doi: $10.1111 /$ area.12071

Castro, L. M., Pio, C. A., Harrison, R. M., and Smith, D. J. T. (1999). Carbonaceous aerosol in urban and rural European atmospheres: estimation of secondary organic carbon concentrations. Atmosph. Environ. 33, 2771-2781. doi: 10.1016/S1352-2310(98)00331-8

Chabas, A., Fouqueau, A., Attoui, M., Alfaro, S. C., Petitmangin, A., Bouilloux, A., et al. (2015). Characterisation of CIME, an experimental chamber for simulating interactions between materials of the cultural heritage and the environment. Environ. Sci. Pollut. Res. 22, 19170-19183. doi: 10.1007/s11356-015-5083-5

Chace, J. F., and Walsh, J. J. (2006). Urban effects on native avifauna: a review. Landscape Urban Plan. 74, 46-69. doi: 10.1016/j.landurbplan.2004.08.007

Chang, L. F., and Huang, S. L. (2015). Assessing urban flooding vulnerability with an emergy approach. Landscape Urban Plan. 143, 11-24. doi: 10.1016/j.landurbplan.2015.06.004

Charalambous, K., Bruggeman, A., and Lange, M. A. (2012). Assessing the urban water balance: the Urban Water Flow Model and its application in Cyprus. Water Sci. Technol. 66, 635-643. doi: 10.2166/wst.2012.188

Chauvin, J. P., Glaeser, E., Ma, Y., and Tobio, K. (2017). What is different about urbanization in rich and poor countries? Cities in Brazil, China, India and the United States. J. Urban Eco. 98, 17-49. doi: 10.1016/j.jue.2016. 05.003

Chen, Y.-C., Pei, L., and Shiau, Y. C. (2015). Application of coastal vegetation to green roofs of residential buildings in Taiwan. Artif. Life Robotics. 20, 86-91. doi: 10.1007/s10015-015-0199-8

Chen, Y.-C., Yao, C.-K., Honjo, T., and Lin, T.-P. (2018). The application of a high-density street-level air temperature observation network (hisan): dynamic variation characteristics of urban heat island in tainan, taiwan. Sci. Total Environ. 626, 555-566. doi: 10.1016/j.scitotenv.2018.01.059

Chiesura,A. (2004). The role of urban parks for the sustainable city. Landscape Urban Plan. 68,129-138. doi: 10.1016/j.landurbplan.2003.08.003

Clarkson, T. S., Martin, R. J., Rudolph, J., and Graham, B. W. L. (1996). Benzene and toluene in New Zealand air. Atmosph. Environ. 30, 569-577. doi: 10.1016/1352-2310(95)00312-6

Cleland, V., Hughes, C., Thornton, L., Venn, A., Squibb, K., and Ball, K. (2015). A qualitative study of environmental factors important for physical activity in rural adults. PLoS ONE 10:140659. doi: 10.1371/journal.pone.0140659

Cohen, P., Potchter, O., and Matzarakis, A. (2013). Human thermal perception of Coastal Mediterranean outdoor urban environments. Appl. Geogr. 37, 1-10. doi: 10.1016/j.apgeog.2012.11.001

Cole, M. A., and Neumayer, E. (2004). Examining the impact of demographic factors on air pollution. Popul. Environ. 26, 5-21. doi: 10.1023/B:POEN.0000039950.85422.eb

Collins, J. P., Kinzig, A., Grimm, N. B., Fagan, W. F., Hope, D., Wu, J., et al. (2000). A new urban ecology: modeling human communities as integral parts of ecosystems poses special problems for the development and testing of ecological theory. Am. Sci. 88, 416-425. doi: 10.1511/2000.5.416

Conticelli, E., and Tondelli, S. (2018). Regenerating with the green: a proposal for the coastal landscape of Senigallia. Territorio della Ricerca su Insediamenti e Ambiente. Int. J. Urban Plan. 20, 91-104. doi: 10.6092/2281-4574/5820

Creswell, J. W., Hanson, W. E., Clark Plano, V. L., and Morales, A. (2007). Qualitative research designs: selection and implementation. Counsel. Psychol. 35, 236-264. doi: $10.1177 / 0011000006287390$ 
Daily, G. C. (2003). "What are ecosystem services," in Global Environmental Challenges for the Twenty-First Century: Resources, Consumption and Sustainable Solutions, ed D. E. Loreley (Wilmington, DE: Scholarly resources Inc.), 227-231.

Dallimer, M., Irvine, K. N., Skinner, A. M., Davies, Z. G., Rouquette, J. R., Maltby, L. L., et al. (2012). Biodiversity and the feel-good factor: understanding associations between self-reported human well-being and species richness. BioScience 62, 47-55. doi: 10.1525/bio.2012.62.1.9

Davis, J. C., and Henderson, J. V. (2003). Evidence on the political economy of the urbanization process. J. Urban Eco. 53, 98-125. doi: 10.1016/S0094-1190(02)00504-1

Dominick, D., Wilson, S. R., Paton-Walsh, C., Humphries, R., Guérette, E. A., Keywood, M., et al. (2018). Characteristics of airborne particle number size distributions in a coastal-urban environment. Atmosph. Environ. 186, 256-265. doi: 10.1016/j.atmosenv.2018.05.031

Donovan, G. H., Butry, D. T., Michael, Y. L., Prestemon, J. P., Liebhold, A. M., Gatziolis, D., et al. (2013). The relationship between trees and human health: evidence from the spread of the emerald ash borer. Am. J. Prevent. Med. 44, 139-145. doi: 10.1016/j.amepre.2012.09.066

Donovan, G. H., and Prestemon, J. P. (2012). The effect of trees on crime in Portland, Oregon. Environ. Behav. 44, 3-30. doi: 10.1177/0013916510383238

Dorney, J. R., Guntenspergen, G. R., Keough, J. R., and Stearns, F. (1984). Composition and structure of an urban woody plant community. Urban Ecol. 8, 69-90. doi: 10.1016/0304-4009(84)90007-X

Douglas, E. M., Kirshen, P. H., Paolisso, M., Watson, C., Wiggin, J., Enrici, A., et al. (2012). Coastal flooding, climate change and environmental justice: Identifying obstacles and incentives for adaptation in two metropolitan Boston Massachusetts communities. Mitig. Adapt. Strat. Global Change. 17, 537-562. doi: 10.1007/s11027-011-9340-8

Eddy, E. N., and Roman, C. T. (2016). Relationship between epibenthic invertebrate species assemblages and environmental variables in Boston Harbor's intertidal habitat. Northeastern Natur. 23, 45-66. doi: $10.1656 / 045.023 .0104$

Eguchi, T., Seminoff, J. A., LeRoux, R. A., Dutton, P. H., and Dutton, D. L. (2010). Abundance and survival rates of green turtles in an urban environment: coexistence of humans and an endangered species. Mar. Biol. 157, 1869-1877. doi: 10.1007/s00227-010-1458-9

Ehrenfeld, J. G. (2000). Evaluating wetlands within an urban context. Urban Ecosyst. 4, 69-85. doi: 10.1023/A:1009543920370

Faeth, S. H., Bang, C., and Saari, S. (2011). Urban biodiversity: patterns and mechanisms. Ann. New York Acad. Sci. 1223, 69-81. doi: $10.1111 / j .1749-6632.2010 .05925 . x$

Fu, Q., Wang, N., Lin, W. N., and Wu, N. (2018). Comparing the Environmental Effects of Terrestrial and Offshore Airports: The Case of Dalian City, China. J. Coast. Res. 103-108. doi: 10.2112/SI84-015.1

Galimany, E., Rose, J. M., Dixon, M. S., and Wikfors, G. H. (2013). Quantifying feeding behavior of ribbed mussels (Geukensia demissa) in two urban sites (Long Island Sound, USA) with different seston characteristics. Estuaries Coasts. 36, 1265-1273. doi: 10.1007/s12237-013-9633-0

Garden, J., McAlpine, C., Peterson, A. N. N., Jones, D., and Possingham, H. (2006). Review of the ecology of Australian urban fauna: a focus on spatially explicit processes. Austral Ecol. 31, 126-148. doi: 10.1111/j.1442-9993.2006. 01578.x

Gardner, E. A. (2003). Some examples of water recycling in Australian urban environments: a step towards environmental sustainability. Water Sci. Techn. Water Supply 3, 21-31. doi: 10.2166/ws.2003.0043

Gasper, R., Blohm, A., and Ruth, M. (2011). Social and economic impacts of climate change on the urban environment. Curr. Opin. Environ. Sustainabil. 3, 150-157. doi: 10.1016/j.cosust.2010.12.009

Giovene di Girasole, E. (2014). The hinge areas for urban regeneration in seaside cities: the High Line in Manhattan, NYC. Adv. Eng. Forum 102-108. doi: 10.4028/www.scientific.net/AEF.11.102

Goh, K. (2019). Urban waterscapes: the hydropolitics of flooding in a sinking city. Int. J. Urban Region. Res. 43, 250-272. doi: 10.1111/1468-2427.12756
Greenwell, C. N., Calver, M. C., and Loneragan, N. R. (2019). Cat gets its tern a case study of predation on a threatened coastal seabird. Animals 9:445. doi: 10.3390/ani9070445

Griggs, D., Stafford-Smith, M., Gaffney, O., Rockström, J., Öhman, M. C., Shyamsundar, P., et al. (2013). Policy: Sustainable development goals for people and planet. Nature 495:305. doi: 10.1038/495305a

Grimm, N. B., Faeth, S. H., Golubiewski, N. E., Redman, C. L., Wu, J., Bai, X., et al. (2008). Global change and the ecology of cities. Science 319, 756-760. doi: 10.1126/science.1150195

Grimm, N. B., Grove, J. G., Pickett, S. T., and Redman, C. L. (2000) Integrated approaches to long-term studies of urban ecological systems: Urban ecological systems present multiple challenges to ecologists-pervasive human impact and extreme heterogeneity of cities, and the need to integrate social and ecological approaches, concepts, and theory. BioScience 50, 571-584. doi: 10.1641/0006-3568(2000)050[0571:IATLTO]2.0.CO;2

Grimm, N. B., Redman, C. L., Boone, C. G., Childers, D. L., Harlan, S. L., and Turner, B. L. (2013). "Viewing the urban socio-ecological system through a sustainability lens: Lessons and prospects from the central Arizona-Phoenix LTER programme," in Long Term Socio-Ecological Research (Dordrecht: Springer), 217-246. doi: 10.1007/978-94-007-1177-8_10

Groffman, P. M., Law, N. L., Belt, K. T., Band, L. E., and Fisher, G. T. (2004), Nitrogen fluxes and retention in urban watershed ecosystems. Ecosystems 7, 393-403. doi: 10.1007/s10021-003-0039-x

Grossmann, I. (2008). Perspectives for Hamburg as a port city in the context of a changing global environment. Geoforum 39, 2062-2072. doi: 10.1016/j.geoforum.2008.04.011

Guerrero Valdebenito, R. M., and Alarcon Rodriguez, M. L. (2018). Neoliberalism and socio-spatial transformations in urban coves of the Metropolitan Area of Concepcion. The cases of Caleta Los Bagres and Caleta Cocholgue, Tome. Rev. Urban. 38:48666. doi: 10.5354/0717-5051.2018.48666

Gumusay, M. U., Koseoglu, G., and Bakirman, T. (2016). An assessment of site suitability for marina construction in Istanbul, Turkey, using GIS and AHP multicriteria decision analysis. Environ. Monitor. Assess. 188:677. doi: $10.1007 / \mathrm{s} 10661-016-5677-5$

Günel, G. (2018). Air conditioning the arabian peninsula. Int. J. Middle East Studies. 50, 573-579. doi: 10.1017/S0020743818000570

Heery, E. C., Olsen, A. Y., Feist, B. E., and Sebens, K. P. (2018). Urbanizationrelated distribution patterns and habitat-use by the marine mesopredator, giant pacific octopus (enteroctopus dofleini). Urban Ecosyst. 21, 707-719. doi: $10.1007 / \mathrm{s} 11252-018-0742-1$

Henry, L., and Wickham, H. (2017). Purrr: Functional Programming Tools. Available online at: https://CRAN.R-project.org/package=purrr (accessed May $4,2021)$.

Holloway, M. G., and Connell, S. D. (2002). Why do floating structures create novel habitats for subtidal epibiota?. Mar. Ecol. Progress Series. 235, 43-52. doi: 10.3354/meps 235043

Hosannah, N., and Gonzalez, J. E. (2014). Impacts of aerosol particle size distribution and land cover land use on precipitation in a coastal urban environment using a cloud-resolving mesoscale model. Adv. Meteorol. 2014:904571. doi: 10.1155/2014/904571

Ip, C. C., Li, X. D., Zhang, G., Wai, O. W., and Li, Y. S. (2007). Trace metal distribution in sediments of the Pearl River Estuary and the surrounding coastal area, South China. Environ. Pollut. 147, 311-323. doi: 10.1016/j.envpol.2006.06.028

James, K. L., Randall, N. P., and Haddaway, N. R. (2016). A methodology for systematic mapping in environmental sciences. Environ. Evid. 5, 1-13. doi: 10.1186/s13750-016-0059-6

Jartun, M., and Pettersen, A. (2010). Contaminants in urban runoff to Norwegian fjords. J. Soils Sediments. 10, 155-161. doi: 10.1007/s11368-009-0181-y

Jonkman, S. N., Hillen, M. M., Nicholls, R. J., Kanning, W., and van Ledden, M. (2013). Costs of adapting coastal defences to sea-level rise-new estimates and their implications. J. Coastal Res. 29, 1212-1226. doi: 10.2112/JCOASTRES-D-12-0 0230.1 
Juchimiuk, J., and Januszkiewicz, K. (2019). "Envisioning infrastructure to reduce disaster's impact to cities during the climate change area being elements of smart cities," in IOP Conference Series: Earth and Environmental Science (Vol. 214) (Krakow: IOP Publishing), 012141. doi: 10.1088/1755-1315/214/1/012141

Kalinowski, R. S., and Johnson, M. D. (2010). Influence of suburban habitat on a wintering bird community in coastal northern California. Condor. 112, 274-282. doi: 10.1525/cond.2010.090037

Kaniewski, D., Van Campo, E., Morhange, C., Guiot, J., Zviely, D., Shaked, I., et al. (2013). Early urban impact on Mediterranean coastal environments. Scient. Rep. 3, 1-5. doi: 10.1038/srep03540

Kantamaneni, K., Gallagher, A., and Du, X. (2019). Assessing and mapping regional coastal vulnerability for port environments and coastal cities. J. Coastal Conserv. 23, 59-70. doi: 10.1007/s11852-018-0636-7

Kates, R. W., Clark, W. C., Corell, R., Hall, J. M., Jaeger, C. C., Lowe, I., et al. (2001). Sustainability science. Science 292, 641-642. doi: 10.1126/science.1059386

Krishnan, S., Lin, J., Simanjuntak, J., Hooimeijer, F., Bricker, J., Daniel, M., et al. (2019). Interdisciplinary design of vital infrastructure to reduce flood risk in tokyo's edogawa ward. Geosciences 9:357. doi: 10.3390/geosciences 9080357

Kulkova, M., Chadov, F., and Davidochkina, A. (2011). Radiocarbon in vegetation of coastal zone of Finnish Bay (Russia). Procedia Environ. Sci. 8, 375-381. doi: 10.1016/j.proenv.2011.10.059

Kumar, T. S., Mahendra, R. S., Nayak, S., Radhakrishnan, K., and Sahu, K. C. (2010). Coastal vulnerability assessment for Orissa State, east coast of India. J. Coastal Res. 26, 523-534. doi: 10.2112/09-1186.1

Kuwae, T., Kanda, J., Kubo, A., Nakajima, F., Ogawa, H., Sohma, A., et al. (2016). Blue carbon in human-dominated estuarine and shallow coastal systems. Ambio 45, 290-301. doi: 10.1007/s13280-015-0725-x

Leclerc, J. C., and Viard, F. (2018). Habitat formation prevails over predation in influencing fouling communities. Ecolo. Evolut. 8, 477-492. doi: 10.1002/ece3.3654

Li, Y., Qiu, J., Zhao, B., Pavao-Zuckerman, M., Bruns, A., Qureshi, S., et al. (2017). Quantifying urban ecological governance: a suite of indices characterizes the ecological planning implications of rapid coastal urbanization. Ecol. Indic. 72, 225-233. doi: 10.1016/j.ecolind.2016.08.021

Li, Y., Yang, X., Zhu, X., Mulvihill, P. R., Matthews, H. D., and Sun, X. (2011). Integrating climate change factors into China's development policy: adaptation strategies and mitigation to environmental change. Ecol. Compl. 8, 294-298. doi: 10.1016/j.ecocom.2011.08.001

Li, Z., Zhou, C., Yang, X., Chen, X., Meng, F., Lu, C., et al. (2018). Urban landscape extraction and analysis in the mega-city of China's coastal regions using highresolution satellite imagery: a case of Shanghai, China. Int. J. Appl. Earth Observ. Geoinform. 72, 140-150. doi: 10.1016/j.jag.2018.03.002

Lim, H. C., and Sodhi, N. S. (2004). Responses of avian guilds to urbanisation in a tropical city. Landscape Urban Plan. 66, 199-215. doi: 10.1016/S0169-2046(03)00111-7

Liu, J., Dietz, T., Carpenter, S. R., Alberti, M., Folke, C., Moran, E., et al. (2007a). Complexity of coupled human and natural systems. Science 317, 1513-1516. doi: 10.1126/science. 1144004

Liu, J., Dietz, T., Carpenter, S. R., Folke, C., Alberti, M., Redman, C. L., et al. (2007b). Coupled human and natural systems. AMBIO 36, 639-649. doi: 10.1579/0044-7447(2007)36[639:CHANS]2.0.CO;2

Lopes, A., Lopes, S., Matzarakis, A., and Alcoforado, M. J. (2011). The influence of the summer sea breeze on thermal comfort in funchal (madeira). A contribution to tourism and urban planning. Meteorol. Zeitschrift 20, 553-564. doi: 10.1127/0941-2948/2011/0248

Luijendijk, A., Hagenaars, G., Ranasinghe, R., Baart, F., Donchyts, G., and Aarninkhof, S. (2018). The state of the world's beaches. Scient. Rep. 8, 1-11. doi: 10.1038/s41598-018-24630-6

Maguire, T. J., and Fulweiler, R. W. (2019). Urban groundwater dissolved silica concentrations are elevated due to vertical composition of historic land-filling. Sci. Total Environ. 684, 89-95. doi: 10.1016/j.scitotenv.2019.05.272

Martin, J. M., French, K., and Major, R. E. (2007). The pest status of Australian white ibis (Threskiornis molucca) in urban situations and the effectiveness of egg-oil in reproductive control. Wildlife Res. 34, 319-324. doi: 10.1071/WR07005

Marzluff, J. M. (2001). "Worldwide urbanization and its effects on birds," in Avian Ecology and Conservation in an Urbanizing World, eds J. M. Marzluff, R. Bowman, and R. Donnelly (Boston: Springer), 19-47. doi: 10.1007/978-1-4615-1531-9
McDonnell, M. J., Pickett, S. T., and Pouyat, R. V. (1993). "The application of the ecological gradient paradigm to the study of urban effects," in Humans as Components of Ecosystems, eds G. E. Likens, and W. J. Cronon (New York, NY: Springer), 175-189. doi: 10.1007/978-1-4612-0905-8_15

McKinney, M. L. (2006). Urbanization as a major cause of biotic homogenization. Biol. Conserv. 127, 247-260. doi: 10.1016/j.biocon.2005.09.005

Mejia, J. F., and Morawska, L. (2009). An investigation of nucleation events in a coastal urban environment in the Southern Hemisphere. Atmosph. Chem. Phys. 9, 2195-2222. doi: 10.5194/acpd-9-2195-2009

Mgelwa, A. S., Hu, Y. L., Liu, J. F., Qiu, Q., Liu, Z., and Ngaba, M. J. Y. (2019). Differential patterns of nitrogen and $\delta 15 \mathrm{~N}$ in soil and foliar along two urbanized rivers in a subtropical coastal city of southern China. Environ. Pollut. 244, 907-914. doi: 10.1016/j.envpol.2018.10.083

Mitsch, W. J. (2012). What is ecological engineering?. Ecol. Eng. 45, 5-12. doi: 10.1016/j.ecoleng.2012.04.013

Morris, R. L., Boxshall, A., and Swearer, S. E. (2020). Climate-resilient coasts require diverse defence solutions. Nat Climate Change 10, 1-3. doi: 10.1038/s41558-020-0798-9

Morris, R. L., Heery, E. C., Loke, L. H., Lau, E., Strain, E., Airoldi, L., et al. (2019). "H4 design options, implementation issues and evaluating success of ecologically engineered shorelines," in Oceanography and Marine Biology: An Annual Review, eds S. J. Hawkings, A. L. Allcock, A. E. Bates, L. B. Firth, I. P. Smith, S. E. Swearer, P. A. and Tood, P. A. (Taylor and Francis), 169-228. doi: 10.1201/9780429026379-4

Nagendra, H., Bai, X., Brondizio, E. S., and Lwasa, S. (2018). The urban south and the predicament of global sustainability. Nat. Sust. 1, 341-349. doi: 10.1038/s41893-018-0101-5

Naidoo, T., Smit, A. J., and Glassom, D. (2016). Plastic ingestion by estuarine mullet Mugil cephalus (Mugilidae) in an urban harbour, KwaZulu-Natal, South Africa. African J. Mar. Sci. 38, 145-149. doi: 10.2989/1814232X.2016.11 59616

Noble, R. T., Griffith, J. F., Blackwood, A. D., Fuhrman, J. A., Gregory, J. B., Hernandez, X., et al. (2006). Multitiered approach using quantitative PCR to track sources of fecal pollution affecting Santa Monica Bay, California. Appl. Environ. Microbiol. 72, 1604-1612. doi: 10.1128/AEM.72.2.1604-1612.2006

Noyes, J. H., and Progulske, D. R. (Eds.). (1974). A Symposium on Wildlife in an Urbanizing Environment, November 27-29. Springfield, MA: (No. 28). Cooperative Extension Service, University of Massachusetts.

Nunkoo, R., and Ramkissoon, H. (2010). Small island urban tourism: a residents' perspective. Curr. Issues Tour. 13, 37-60. doi: 10.1080/13683500802499414

Ogie, R. I., Adam, C., and Perez, P. (2020). A review of structural approach to flood management in coastal megacities of developing nations: current research and future directions. J. Environ. Plann. Manag. 63, 127-147. doi: 10.1080/09640568.2018.1547693

O'Shaughnessy, K. A., Hawkins, S. J., Evans, A. J., Hanley, M. E., Lunt, P., Thompson, R. C., et al. (2020). Design catalogue for eco-engineering of coastal artificial structures: a multifunctional approach for stakeholders and end-users. Urban Ecosyst. 23, 431-443. doi: 10.1007/s11252-019-0 0924-z

Pacione, M. (2003). Urban environmental quality and human wellbeing-a social geographical perspective. Landscape Urban Plan. 65, 19-30. doi: $10.1016 /$ S0169-2046(02)0 0234-7

Pallarés, S., Gómez, E., Martínez, A., and Jordán, M. M. (2019). The relationship between indoor and outdoor levels of PM10 and its chemical composition at schools in a coastal region in Spain. Heliyon 5:e02270. doi: 10.1016/j.heliyon.2019.e02270

Papatheochari, T., and Coccossis, H. (2019). Development of a waterfront regeneration tool to support local decision making in the context of integrated coastal zone management. Ocean Coastal Manag. 169, 284-295. doi: 10.1016/j.ocecoaman.2018.12.013

Parzych, A., Astel, A., Zduńczyk, A., and Surowiec, T. (2016). Evaluation of urban environment pollution based on the accumulation of macro-and trace elements in epiphytic lichens. J. Environ. Sci. Health Part A. 51, 297-308. doi: 10.1080/10934529.2015.1109387

Patel, P., Ghosh, S., Kaginalkar, A., Islam, S., and Karmakar, S. (2019). Performance evaluation of WRF for extreme flood forecasts in a coastal urban environment. Atmosph. Res. 223, 39-48. doi: 10.1016/j.atmosres.2019. 03.005 
Patz, J. A., Daszak, P., Tabor, G. M., Aguirre, A. A., Pearl, M., Epstein, J., et al. (2004). Unhealthy landscapes: policy recommendations on land use change and infectious disease emergence. Environ. Health Perspect. 112, 1092-1098. doi: 10.1289/ehp.6877

Paul, M. J., and Meyer, J. L. (2001). Streams in the urban landscape. Ann. Rev. Ecol. Syst. 32, 333-365. doi: 10.1146/annurev.ecolsys.32.081501.114040

Peng, C., Wang, S., Zhang, J., Lim, C. C., and Ooi, L. K. (2011). "Sustainable in-situ water resource management strategies in water scarce urban environment: a case study of sino-singapore tianjin eco city," in 2011 Asia-Pacific Power and Energy Engineering Conference (Wuhan: IEEE), 1-4. doi: 10.1109/APPEEC.2011.5748622

Peng, F., Wong, M. S., Wan, Y., and Nichol, J. E. (2017). Modeling of urban wind ventilation using high resolution airborne LiDAR data. Comp. Environ. Urban Syst. 64, 81-90. doi: 10.1016/j.compenvurbsys.2017.01.003

Perkol-Finkel, S., Hadary, T., Rella, A., Shirazi, R., and Sella, I. (2018). Seascape architecture-incorporating ecological considerations in design of coastal and marine infrastructure. Ecol. Eng. 120, 645-654. doi: 10.1016/j.ecoleng.2017.06.051

Pickett, S. T., Cadenasso, M. L., Childers, D. L., McDonnell, M. J., and Zhou, W. (2016). Evolution and future of urban ecological science: ecology in, of, and for the city. Ecosyst. Health Sust. 2:e01229. doi: 10.1002/ehs 2.1229

Pickett, S. T., Cadenasso, M. L., Grove, J. M., Groffman, P. M., Band, L. E., Boone, C. G., et al. (2008). Beyond urban legends: an emerging framework of urban ecology, as illustrated by the Baltimore Ecosystem Study. BioScience 58, 139-150. doi: 10.1641/B580208

Pinheiro, A. T. K., and Hokugo, A. (2019). Effectiveness of early warning and community cooperation for evacuation preparedness from mega-risk type coastal hazard in childcare centers. Int J. Disaster Resilience Built Environ 4, 269-275. doi: 10.1108/IJDRBE-05-2019-0023

Pizarro, R. E. (2008). "Sustainable planning for poor communities: urban design studios as a catalyst for development in Colombia," in Dialogues in Urban Planning: Towards Sustainable Regions, eds T. Gilmour, E. J. Blakely, and R. E. Pizarro (Sidney, NSW: Sidney University Press), 175-194.

Priestley, M., Breton, M. L., Bannan, T. J., Worrall, S. D., Bacak, A., Smedley, A. R., et al. (2018). Observations of organic and inorganic chlorinated compounds and their contribution to chlorine radical concentrations in an urban environment in northern Europe during the wintertime. Atmosph. Chem. Phys. 18, 13481-13493. doi: 10.5194/acp-18-13481-2018

Punda-Polić, V., Bradarić, N., Klišmanić-Nuber, Z., Mrljak, V., and Giljanovi,ć, M. (1995). Antibodies to spotted fever group rickettsiae in dogs in Croatia. Europ. J. Epidem. 11, 389-392. doi: 10.1007/BF01721222

Pushpawela, B., Jayaratne, R., and Morawska, L. (2018). Differentiating between particle formation and growth events in an urban environment. Atmosph. Chem. Phys. 18, 11171-11183. doi: 10.5194/acp-18-11171-2018

R Core Team. (2020). R: A Language and Environment for Statistical Computing. Vienna, Austria: R Foundation for Statistical Computing. Available online at: https://www.R-project.org/

Race, D., Luck, G. W., and Black, R. (2010). "Patterns, drivers and implications of demographic change in rural landscapes," in Demographic Change in Australia's Rural Landscapes, G. W. Luck, D. Race, and R. Black (Dordrecht: Springer), 1-22. doi: 10.1007/978-90-481-9654-8_1

Redman, C. L., Grove, J. M., and Kuby, L. H. (2004). Integrating social science into the long-term ecological research (LTER) network: social dimensions of ecological change and ecological dimensions of social change. Ecosystems 7, 161-171. doi: 10.1007/s10021-003-0215-z

Rees, W. E. (1997). Urban ecosystems: the human dimension. Urban Ecosyst. 1, 63-75. doi: 10.1023/A:1014380105620

Reyes-López, J., and Carpintero, S. (2014). Comparison of the exotic and native ant communities (Hymenoptera: Formicidae) in urban green areas at inland, coastal and insular sites in Spain. Europ. J. Entomol. 111:421. doi: 10.14411/eje.2014.044

Robinson, D. (2014). Broom: an R package for converting statistical analysis objects into tidy data frames. arXiv [Preprint] arXiv:1412.3565.

Rosenzweig, B. R., Groffman, P. M., Zarnoch, C. B., Branco, B. F., Hartig, E. K., Fitzpatrick, J., et al. (2018). Nitrogen regulation by natural systems in "unnatural" landscapes: denitrification in ultra-urban coastal ecosystems. Ecosyst. Health Sust. 4, 205-224. doi: 10.1080/20964129.2018.1527188
RStudio Team (2019). RStudio: Integrated Development for R. Boston, MA RStudio, Inc. Available online at: http://www.rstudio.com/.

Sahal, A., Leone, F., and Péroche, M. (2013). Complementary methods to plan pedestrian evacuation of the French Riviera's beaches in case of tsunami threat: graph-and multi-agent-based modelling. Nat. Hazards Earth Syst. Sci. 13, 1735-1743. doi: 10.5194/nhess-13-1735-2013

Sainz-Borgo, C., Giner, S., González-Carcacía, J. A., Caula, S., Fernández-Ordóñez, J. C., Hernández, C., et al. (2016). Current distribution, habitat use, and breeding records of the house sparrow (Passer domesticus) in Venezuela. Ornitol. Neotrop. 27, 267-273.

Sairinen, R., and Kumpulainen, S. (2006). Assessing social impacts in urban waterfront regeneration. Environ. Impact Assess. Rev. 26, 120-135. doi: 10.1016/j.eiar.2005.05.003

Santos, T., and Freire, S. (2015). Testing the contribution of Worldview2 improved spectral resolution for extracting vegetation cover in urban environments. Canad. J. Remote Sensing. 41, 505-514. doi: 10.1080/07038992.2015.1110011

Semadeni-Davies, A., Hernebring, C., Svensson, G., and Gustafsson, L. G. (2008). The impacts of climate change and urbanisation on drainage in Helsingborg, Sweden: Combined sewer system. J. Hydrol. 350, 100-113. doi: 10.1016/j.jhydrol.2007.05.028

Serre, D., Barroca, B., and Diab, Y. (2010). "Urban flood mitigation: Sustainable options," in The Sustainable City VI, Urban Regenerations and Sustainability, Vol 129 (Southampton: WIT press), 299-309. doi: 10.2495/SC1 00261

Shanquan, L., Zhang, G., Yang, J., and Nan, J. (2016). Multi-source characteristics of atmospheric deposition in Nanjing, China, as controlled by East Asia monsoons and urban activities. Pedosphere 26, 374-385. doi: 10.1016/S1002-0160(15)60050-9

Shepard, E. L., Williamson, C., and Windsor, S. P. (2016). Fine-scale flight strategies of gulls in urban airflows indicate risk and reward in city living. Philosoph. Trans. R. Soc. B Biol. Sci. 371:20150394. doi: 10.1098/rstb.2015.0394

Sherbinin, A. D., Carr, D., Cassels, S., and Jiang, L. (2007). Population and environment. Ann. Rev. Environ. Resour. 32, 345-373. doi: 10.1146/annurev.energy.32.041306.100243

Shochat, E., Warren, P. S., and Faeth, S. H. (2006). Future directions in urban ecology. Trends Ecol. Evol. 21, 661-662. doi: 10.1016/j.tree.2006.09.007

Smith, A. C., and Munro, U. (2010). Seasonal population dynamics of the Australian White Ibis (Threskiornis molucca) in urban environments. Emu. 110, 132-136. doi: 10.1071/MU09072

Song, X., Chang, K. T., Yang, L., and Scheffran, J. (2016). Change in environmental benefits of urban land use and its drivers in Chinese cities, 2000-2010. Int. J. Environ. Res. Public Health. 13:535. doi: 10.3390/ijerph13060535

Stathopoulou, M., and Cartalis, C. (2007). Daytime urban heat islands from Landsat ETM+ and Corine land cover data: An application to major cities in Greece. Solar Energy 81, 358-368. doi: 10.1016/j.solener.2006.06.014

Storch, H., and Downes, N. K. (2011). A scenario-based approach to assess Ho Chi Minh City's urban development strategies against the impact of climate change. Cities 28, 517-526. doi: 10.1016/j.cities.2011.07.002

Su, X., Liu, T., Beheshti, M., and Prigiobbe, V. (2019). Relationship between infiltration, sewer rehabilitation, and groundwater flooding in coastal urban areas. Environ. Sci. Pollut. Res. 27, 1-11. doi: 10.1007/s11356-019-06513-z

Sukopp, H. (1998). "Urban ecology-scientific and practical aspects," in Urban Ecology, eds J. Breuste, H. Feldmann, and O. Uhlmann (Berlin: Springer), 3-16. doi: 10.1007/978-3-642-88583-9_1

Surjan, A. K., and Shaw, R. (2008). 'Eco-city'to 'disaster-resilient eco-community': a concerted approach in the coastal city of Puri, India. Sust. Sci. 3, 249-265. doi: 10.1007/s11625-008-0051-3

Sutton-Grier, A. E., Wowk, K., and Bamford, H. (2015). Future of our coasts: the potential for natural and hybrid infrastructure to enhance the resilience of our coastal communities, economies and ecosystems. Environ. Sci. Policy 51, 137-148. doi: 10.1016/j.envsci.2015.04.006

Tait, C. J., Daniels, C. B., and Hill, R. S. (2005). Changes in species assemblages within the Adelaide metropolitan area, Australia, 1836-2002. Ecol. Appl. 15, 346-359. doi: 10.1890/04-0920

Theodosi, C., Tsagkaraki, M., Zarmpas, P., Grivas, G., Liakakou, E., Paraskevopoulou, D., et al. (2018). Multi-year chemical composition of the fine-aerosol fraction in Athens, Greece, with emphasis on the contribution 
of residential heating in wintertime. Atmosph. Chem. Phys. 18, 14371-14391. doi: 10.5194/acp-18-14371-2018

Torresan, S., Critto, A., Dalla Valle, M., Harvey, N., and Marcomini, A. (2008). Assessing coastal vulnerability to climate change: comparing segmentation at global and regional scales. Sust. Sci. 3, 45-65. doi: 10.1007/s11625-008-0045-1

Tu, W., and Shi, C. (2006). Urban environmental management in Shanghai: achievements, problems, and prospects. Environ. Manag. 37, 307-321. doi: 10.1007/s00267-003-0155-6

Tzortzakaki, O., Kati, V., Kassara, C., Tietze, D. T., and Giokas, S. (2018). Seasonal patterns of urban bird diversity in a Mediterranean coastal city: the positive role of open green spaces. Urban Ecosyst. 21, 27-39. doi: 10.1007/s11252-017-0695-9

Tzoulas, K., Korpela, K., Venn, S., Yli-Pelkonen, V., Kazmierczak, A., Niemela, J., et al. (2007). Promoting ecosystem and human health in urban areas using Green Infrastructure: a literature review. Landscape Urban Plan. 81, 167-178. doi: 10.1016/j.landurbplan.2007.02.001

Ulrich, R. S. (1984). View through a window may influence recovery from surgery. Science 224, 420-421. doi: 10.1126/science.6143402

United Nations. (2014). Department of Economics and Social Affairs Population Dynamics. World Urbanization Prospects: The 2014 Revision. New York, NY: Highlights.

United Nations. (2017). "Concept paper. Partnership dialogue 2: managing protecting, conserving and restoring marine and coastal ecosystems," in The Ocean Conference (New York, NY: United Nations).

United Nations. (2018). Department of Economics and Social Affairs Population Dynamics. World Urbanization Prospects: The 2018 Revision. Key facts, New York, NY.

United Nations. (2019). Department of Economics and Social Affairs Population Dynamics. World population prospects: Download Files. Available online at: https://population.un.org/wpp/Download/Standard/CSV/

Van Kamp, I., Leidelmeijer, K., Marsman, G., and De Hollander, A. (2003). Urban environmental quality and human well-being: towards a conceptual framework and demarcation of concepts; a literature study. Landscape Urban Plan. 65, 5-18. doi: 10.1016/S0169-2046(02)00232-3

Vicente, A. B., Sanfeliu, T., and Jordan, M. M. (2012). Assesment of PM10 pollution episodes in a ceramic cluster (NE Spain): proposal of a new quality index for PM10, As, Cd, Ni and Pb. J. Environ. Manag. 108, 92-101. doi: 10.1016/j.jenvman.2012.04.032

Villagra, P., Herrmann, G., Quintana, C., and Sepúlveda, R. D. (2016). Resilience thinking and urban planning in a coastal environment at risks of tsunamis: the case study of Mehuín, Chile. Rev Geogr Norte Grande 64, 63-82. doi: $10.4067 /$ S0718-34022016000200006

Vitousek, S., Barnard, P. L., Fletcher, C. H., Frazer, N., Erikson, L., and Storlazzi, C. D. (2017). Doubling of coastal flooding frequency within decades due to sea-level rise. Scient. Rep. 7, 1-9. doi: 10.1038/s41598-017-01362-7

Vye, D., and Rousseaux, F. (2010). Evaluation of urban planning strategies with a versatile urban growth model. Sust. City VI Urban Regener. Sust. 6:227. doi: 10.2495/SC100201

Walsh, C. J., Roy, A. H., Feminella, J. W., Cottingham, P. D., Groffman, P. M., and Morgan, R. P. (2005). The urban stream syndrome: current knowledge and the search for a cure. J. North Am. Benthol. Soc. 24, 706-723. doi: 10.1899/04-028.1

Wang, Z., Yan, C., Kong, H., and Wu, D. (2010). "Mechanisms of cadmium toxicity to various trophic saltwater organisms," in Cadmium in the Environment, ed R. G. Parvau (New York, NY: Nova Science Publishers Inc.), 297-336.

Washburn, B. E., Bernhardt, G. E., Kutschbach-Brohl, L., Chipman, R. B., and Francoeur, L. C. (2013). Foraging ecology of four gull species at a coastal-urban interface: ecología de forrajeo de cuatro especies de gaviota en una interface costera-urbana. Condor 115, 67-76. doi: 10.1525/cond.2013.110185

Watson, D., and Adams, M. (2010). Design for Flooding: Architecture, Landscape, and Urban Design for Resilience To Climate Change. Hoboken, NJ: John Wiley and Sons. doi: 10.1002/9781118259870

Watson, J. (2015). Practical precautions, reasonable responses: how South Australia's planning regime adapts to the coastal impacts of climate change. Environ. Plann. Law J. 32, 256-277.

Way, J. G., Ortega, I. M., and Strauss, E. G. (2004). Movement and activity patterns of eastern coyotes in a coastal, suburban environment. Northeast. Natur. 11, 237-254. doi: 10.1656/1092-6194(2004)011[0237:MAAPOE]2.0.CO;2

Weinstein, M. P. (2009). The road ahead: The sustainability transition and coastal research. Estuaries Coasts 32, 1044-1053. doi: 10.1007/s12237-009-9221-5
Whisson, D. A., Weston, M. A., and Shannon, K. (2015). Home range, habitat use and movements by the little raven (Corvus mellori) in a coastal peri-urban landscape. Wildlife Res. 42, 500-508. doi: 10.1071/WR15039

White, M. P., Pahl, S., Ashbullby, K., Herbert, S., and Depledge, M. H. (2013). Feelings of restoration from recent nature visits. J. Environ. Psychol. 35, 40-51. doi: 10.1016/j.jenvp.2013.04.002

Wickham, H. (2016). ggplot2: Elegant Graphics for Data Analysis. UseR. New York, NY: Springer. doi: 10.1007/978-3-319-24277-4_9

Wickham, H. (2019). Stringr: Simple, Consistent Wrappers for Common String Operations. Available online at: https://CRAN.R-project.org/package=stringr (accesed May 4, 2021).

Wickham, H., Averick, M., Bryan, J., Chang, W., McGowan, L. D. A., François, R., et al. (2019a). Welcome to the tidyverse. J. Open Source Softw. 4:1686. doi: 10.21105 /joss. 01686

Wickham, H., François, R., Henry, L., and Müller, K. (2019b). dplyr: A Grammar of Data Manipulation. Available online at: https://CRAN.R-project.org/package= dplyr (accessed May 4, 2021).

Wolch, J. R., Byrne, J., and Newell, J. P. (2014). Urban green space, public health, and environmental justice: The challenge of making cities 'just green enough'. Landscape Urban Plan. 125, 234-244. doi: 10.1016/j.landurbplan.2014.01.017

Wolsko, C., and Marino, E. (2016). Disasters, migrations, and the unintended consequences of urbanization: What's the harm in getting out of harm's way? Popul. Environ. 37, 411-428. doi: 10.1007/s11111-015-0248-1

Wong, T. C. (2011). "Eco-cities in China: Pearls in the sea of degrading urban environments?," in Eco-City Planning, eds T. C. Wong, and B. Yuen (Dordrecht: Springer), 131-150. doi: 10.1007/978-94-007-0383-4_7

$\mathrm{Wu}$, J. (2014). Urban ecology and sustainability: The state-of-thescience and future directions. Landscape Urban Plan. 125, 209-221. doi: 10.1016/j.landurbplan.2014.01.018

$\mathrm{Wu}, \mathrm{J}$. J. (2008). Making the case for landscape ecology an effective approach to urban sustainability. Landscape J. 27, 41-50. doi: 10.3368/lj.27.1.41

$\mathrm{Wu}, \mathrm{W}$. (2007). Coastline evolution monitoring and estimation-a case study in the region of Nouakchott, Mauritania. Int. J. Remote Sens. 28, 5461-5484. doi: 10.1080/01431160701227612

Yamazaki, K., Kitamoto, T., Yariyama, Y., and Sugiura, S. (2007). An analysis of spatial distribution in the exotic slug caterpillar Parasa lepida (Cramer)(Lepidoptera: Limacodidae) at an urban coastal site in central Japan. Pan-Pacific Entomol. 83, 193-199. doi: 10.3956/0031-0603-83.3.193

Yin, J., Lin, N., and Yu, D. (2016). Coupled modeling of storm surge and coastal inundation: a case study in New York City during Hurricane Sandy. Water Resour. Res. 52, 8685-8699. doi: 10.1002/2016WR0 19102

Yu, W., Zhang, Y., Zhou, W., Wang, W., and Tang, R. (2019). Urban expansion in Shenzhen since 1970s: A retrospect of change from a village to a megacity from the space. Phys. Chem. Earth, Parts A/B/C. 110, 21-30. doi: 10.1016/j.pce.2019.02.006

Zhang, L., Xia, Y. P., Wu, Q., She, L. F., Li, H., and Ruan, T. L. (2014). "Original design and ecological recreation: a comparative analysis of wetland parks in the Yangtse River Delta area," in XXIX International Horticultural Congress on Horticulture: Sustaining Lives, Livelihoods and Landscapes (IHC2014): V 1108, Brisbane: International Society for Horticultural Science (ISHS), 241-248 doi: 10.17660/ActaHortic.2016.1108.31

Zhen, L., Lin, D. M., Shu, H. W., Jiang, S., and Zhu, Y. X. (2007). District cooling and heating with seawater as heat source and sink in Dalian, China. Renew. Energy. 32, 2603-2616. doi: 10.1016/j.renene.2006. 12.015

Conflict of Interest: The authors declare that the research was conducted in the absence of any commercial or financial relationships that could be construed as a potential conflict of interest.

Copyright (๑ 2021 Graells, Nakamura, Celis-Diez, Lagos, Marquet, Pliscoff and Gelcich. This is an open-access article distributed under the terms of the Creative Commons Attribution License (CC BY). The use, distribution or reproduction in other forums is permitted, provided the original author(s) and the copyright owner(s) are credited and that the original publication in this journal is cited, in accordance with accepted academic practice. No use, distribution or reproduction is permitted which does not comply with these terms. 